\title{
Fish-based remedies in Spanish ethnomedicine: a review from a historical perspective
}

\author{
José Ramón Vallejo ${ }^{1 *}$ and José Antonio González²
}

\begin{abstract}
Background: Fish-based therapeutics is fundamentally based on a dietary use, but these vertebrates have also been employed in the treatment of infectious and parasitic diseases, during pregnancy, childbirth and postpartum and to deal with diseases of the different systems.

Methods: An overview of the ethnomedical and historical Spanish literature has been carried out. Automated searches in the most important national and international databases have been performed. All related works have been thorough examined.

Results: We examine the historical use of 54 medicinal fish species, 48 marine and six from inland waters. As useful, in Ancient times 39 species have been recorded (of which only 21 have been collected in subsequent periods), seven in the Middle Ages, 18 in Modern times and 17 in the contemporary period. Anguilla anguilla, Engraulis encrasicolus or Scyliorhinus canicula are species that have survived over time as an ingredient in Spanish folk remedies. Most remedies used in the last century and currently are empirical remedies based on the humorism theory and the principle of contraria contrariis curantur (74\%), and the rest (26\%) are magical type remedies that complete the popular therapeutic arsenal.

Conclusions: In the last century we find a progressive decrease in the number of fish species used in ethnomedicine. Only seven taxa have been documented as surviving therapeutic resources since centuries ago. The existence of a dynamic Spanish ethnomedicine has also been detected which has managed to generate new therapeutic resources in recent times. It is important to validate the remedies by ethnopharmacology and evidence-based medicine. In order to recover as much data as possible, it will be necessary to draw up an inventory of ethnoichthyological uses.
\end{abstract}

Keywords: Ethnozoology, Ethnomedicine, Fish, Medical history, Medical anthropology, Spain

\section{Background}

Ethnozoology is an emerging field in many areas of the world and it is divided, due to its multidisciplinary character [1], into branches of knowledge such as ethnoentomology, ethnoherpetology or ethnoornithology [2-4].

Fishes have a long history of interaction with humans, thus "ethnoichthyology" is acquiring an important role in ethnozoological research [5-7]. There are some studies that discuss the role of ichthyofauna in traditional medicines, mainly in fishing communities [8-12], and that reveal a large number of fish species used in zootherapy, understood as the medicinal use of animals and

\footnotetext{
* Correspondence: joseramonvallejo@unex.es

'Departamento de Terapéutica Médico-Quirúrgica, Facultad de Medicina, Universidad de Extremadura, E-06006 Badajoz, Spain

Full list of author information is available at the end of the article
}

animal-derived products to treat illnesses and health conditions $[13,14]$.

These works on zootherapy are a very useful tool in the exploration of pharmacologically active substances $[15,16]$. But also there are other reasons of an anthropological kind for carrying out these ethnozoological studies. For example, they can help us in the understanding of the human behavior toward health care and the use-consumption of fish resources. As well, in many developing countries these studies have a great value in fish diversity conservation [17-19].

In Spain there has not been any ethnozoology development and only very few articles have been published with an ethnobiological approach, although some anthropological, folk and ethnomedicinal studies have 
focused on the connections between human society and animals [20-23]. This has affected the study of the interactions between humans and fish (ethnoichthyology), and the zootherapy based on these vertebrates is a field of research that has not been given due attention and must therefore be constructed from a framework of an "historical ethnozoology". Following this philosophy, this paper illustrates the use of fishes in Spanish ethnomedicine and its historical development as a therapeutic resource. It provides an inventory of the species that have been used for medicinal purposes from ancient times to the present, and analyses the medical use of fishes in the 20th century.

Thus, our main objective is to obtain an inventory of the fish species that have been used in Spain for therapeutic purposes from antiquity to the present. From this we determine which medicinal species have survived to recent times and what diseases or medical conditions they have been used for.

\section{Methods \\ Procedures}

The present study forms part of a project revision of the ethnozoology in Spain, for which various databases have been examined: ISI Web of Science and Anthropology Plus, JSTOR III - Arts and Sciences, TESEO, the information system of the databases of the Consejo Superior de Investigaciones Científicas (CSIC), the bibliographic website Dialnet, Google Scholar, and the catalogue of Public State Libraries (BPE). The search focused on the type of documents contained in folklore, ethnographic, history of medicine and social and medical anthropology studies. The key words used were: anthropology, history of medicine, ethnomedicine, folk medicine, folklore, zoology, ethnozoology and ethnoichthyology, and the names of the different fish groups in Spanish or English, as appropriate. The search framework also made use of a list of zoonyms contained in Spanish dictionaries [24], and a directory with the names of the most relevant authors of therapeutics throughout history.

The search results were catalogued and the information was classified into ichthyologic groups and historical periods, according to the classical periodization followed by Christoph Cellarius (1638-1707) and those recently employed by De Vos [25]. A total of 52 documents have been analyzed [26-78], of which approximately $8 \%$ belong to Ancient history, $10 \%$ to Medieval, $10 \%$ to "Modern" (6\% to 15 th-17th centuries and $4 \%$ to 18 th-19th centuries, respectively), and $72 \%$ to "contemporary history", i.e. from beginning 20th century to present (Table 1).

The method of identification of the fish species consisted of a discriminatory analysis of the biological, ecological and ethological information, and of the vernacular nomenclature contained in the works consulted. This was all corroborated with catalogues of names, single-access or dichotomous keys of fish [79-82], and ichthyological databases and species identification websites [83-87]. The assessments have been made from Spanish species, although in some cases taxa from other jurisdictional waters or maritime territories have been considered. Those valid scientific names included in the Species 2000 and ITIS Catalogue of Life: 2013 Annual Checklist [88], are considered in the list of species. The species of most historic importance have been established according to their inclusion in the remedies belonging to the 20th century and at least one previous era.

The illnesses treated with the species mentioned are classified using the chapters of the International Statistical Classification of Diseases and Related Health Problems $10^{\text {th }}$ Revision, ICD-10 (Version: 2010) [89]. Taking into account the species employed in the past century, the relative importance of each group of diseases $\left(\mathrm{IC}_{\mathrm{i}}\right)$ in Spanish ethnomedicine has been calculated. A calculation has been made of the relationship between the number of useful species registered for each chapter $\left(C_{i}\right)$ and the number obtained for the chapter with greatest species richness $\left(C_{\max }\right)$; i.e. $I_{i}=C_{i} / C_{\max }$.

\section{Data analysis}

The Spanish ethnomedicine applies to medical ideas and practices with magical, religious and natural (empirical) background $[43,45,49,64,71]$. In this regard, we have classified all the documented remedies despite difficulties in establishing boundaries for this kind of work review method since remedies based on empirical knowledge are found as well as magical-religious therapies with both empirical and esoteric bases. In accordance with the previously mentioned, the categories for type of remedy are as follows: "magical remedies" and "empirical remedies" (i.e., natural medicine home remedies for those using fish parts for therapeutic means starting from an empirical base).

On the other hand, to evaluate the route of administration of the remedies, we consider two categories: "internal use" and "external use".

All these are categories make up the variables studied in a test of independence once the values obtained in two-by-two contingency tables were included. The Pearson's chi-squared test $\left(\chi^{2}\right)$ was used to answer the question of no association between variables. This test rejects the null hypothesis (of independence) for statistic values too big to be attributed to random chance. All of this allows us to answer the following key question: The fish-based remedies that have survived in the Spanish ethnomedicine have similar features to those remedies listed in the most relevant historical references? 
Table 1 List of references consulted

Ref. Historical period [text used]

\section{Ancient}

[26] Pliny the Elder (23-79 AD) -Naturalis Historia- [Cantó et al., 2007]

[27] Pedanius Dioscorides (ca. 49-90 AD) -De Materia Medica[López Eire, 2006]

[28] Claudius Aelianus (ca. 175-235 AD) [Vara Donado, 1989]

[29] El libro de San Cipriano (4th century) [facsimile edition 1985]

\section{Medieval}

[30] Abd al-Malik Ibn Habib (9th century) [Álvarez de Morales and Girón Irueste, 1992]

[31] Abulcasis (936-1013) [Arvide Cambra, 2010]

[32] Ibn Wafid (1008-1074) [Álvarez de Morales, 2006]

[33] Ibn al-Baytar al-Malaqi (ca. 1180-1248) [Cabo González, 2005]

[34] Ibn al-Durayhim al-Mawsili (14th century) [Ruiz Bravo-Villasante, 1980]

"Modern" - 15th-17th centuries

[35] Johannes de Cuba -Hortus Sanitatis (1491)- Viñayo and Riesco, 1998]

[36] Vélez de Arciniega (1613)

[37] Daza Chacón (1673)

\section{"Modern" - 18th-19th centuries}

[38] Palacios (1792)

[39] Collin de Plancy (1842)

\section{"Contemporary" - 20th century-at present}

[40] Nogales (1907)

[41] Rodríguez López (1910)

[42] Sánchez Pérez (1948)

[43] Barriola (1952)

[44] Cascón (1952)

[45] Castillo de Lucas (1958)

[46] Seijo Alonso (1974)

[47] Alvar (1979-1983)

[48] Becoña Iglesias (1981)

[49] Carril (1981)

[50] Blanco (1985)

[51] Erkoreka (1988)

[52] Vázquez Gallego (1989)

[53] Barandiarán (1990)

[54] García Arambilet (1990)

[55] Garmendia Larrañaga (1990)

[56] Carril (1991)

[57] Jordán and De la Peña (1992)
Table 1 List of references consulted (Continued)
[58] Fragua Gil (1994)
[59] Gil Barberá and Martí Mora (1997)
[60] Domínguez Moreno (2000)
[61] Dueso (2001)
[62] Erkoreka (2002)
[63] Álvarez Peña (2004)
[64] Barandiarán and Manterola (2004)
[65] Domínguez Moreno (2004)
[66] González Salgado (2004)
[67] López Pérez (2004)
[68] Domínguez Moreno (2005)
[69] Vallejo et al. (2005)
[70] Hernández Ortega (2007)
[71] Pérez Vidal (2007)
[72] Castelló et al. (2008)
[73] Muriel Martín (2008)
[74] Pardo de Santayana (2008)
[75] Vallejo (2008)
[76] Alemany et al. (2010)
[77] Cobo López and Tijera Jiménez (2013)
[78] Rigat et al. (2013)

\section{Results and discussion}

A total of 54 fish species, 48 marine and fresh-water six (Anguilla anguilla -a catadromous fish-, Cyprinus carpio, Luciobarbus sclateri, Perca fluviatilis, Salmo trutta and Silurus glanis), have been identified. In most cases ( $90 \%)$ the reported vernacular names have been associated with scientific names. Five fish had two or more possible species names associated within the Spanish geographical area. Also, there have been 14 vernacular names that were impossible to match with one taxon, due to a lack of biological, historical and/or philological data; these fishes are named as: "al-manun", "baraqa", "cerusa", "haziba", "kunckut", "kurbuy", "laser", "lengua de toro", "pagro de río", "qita", "rubayta", "rubellio", "sahannah" and "sumayka". We also found remedies based on the use of "garo/garum", "fish", "salted", "brine fish", "fish jelly" or "fish tail". All these data are not included in our study.

Table 2 shows the relationship of inventoried taxa, the vernacular names and the historical times in which their medicinal uses were recorded. A total of 39 fish were used in Ancient times, seven in the Medieval period, 18 in the "Modern" and 17 in the contemporary period. The description of the compiled remedies is included in Table 3. 
Table 2 Overview of medically important fish species, indicating the different eras in which they have been used Fish species Vernacular name(s)

Historical periods

Ancient Medieval Modern Contemporary

Acipenser sturio Linnaeus, 1758

Anguilla anguilla (Linnaeus, 1758

Argyrosomus regius (Asso, 1801)

Brama brama (Bonnaterre, 1788)

Clupea harengus harengus Linnaeus, 1758

Coris julis (Linnaeus, 1758)

Crystallogobius linearis (Düben, 1845)

Cyprinus carpio Linnaeus, 1758

Dasyatis pastinaca (Linnaeus, 1758)

Dicologoglossa cuneata (Moreau, 1881)

Dipturus batis (Linnaeus, 1758)

Engraulis encrasicolus (Linnaeus, 1758)

Gadus morhua Linnaeus, 1758

Galeorhinus galeus (Linnaeus, 1758)

Halobatrachus didactylus (Bloch \& Schneider, 1801)

Hippocampus hippocampus (Linnaeus, 1758);

H. guttulatus Cuvier, 1829

Lophius piscatorius Linnaeus, 1758

Luciobarbus sclateri (Günther, 1868)

Merlangius merlangus (Linnaeus, 1758)

Merluccius merluccius (Linnaeus, 1758)

Mugil cephalus Linnaeus, 1758

Mullus barbatus barbatus Linnaeus, 1758

M. surmuletus Linnaeus, 1758

Muraena helena Linnaeus, 1758

Ophisurus serpens (Linnaeus, 1758)

Oreochromis niloticus niloticus (Linnaeus, 1758)

Oxynotus centrina (Linnaeus, 1758)

Pagellus erythrinus (Linnaeus, 1758)

Perca fluviatilis Linnaeus, 1758

Raja clavata Linnaeus, 1758; R. microocellata (Montagu, 1818); Raya

R. miraletus Linnaeus, 1758; Leucoraja naevus (Müller \& Henle, 1841)

Remora remora (Linnaeus, 1758)

Salmo trutta Linnaeus, 1758

Sarda sarda (Bloch, 1793)

Sardina pilchardus (Walbaum, 1792)

Sciaena umbra Linnaeus, 1758

Scophthalmus maximus (Linnaeus, 1758)

Scorpaena porcus Linnaeus, 1758

Scorpaena scrofa Linnaeus, 1758
Esturión, sollo

Anguila, anguilla

Corvina, curvina, corbina

Japuta

Arenque

Julis

Gobio

Carpa

Pastinaca, pastinaca marina

Acedía

Noriega

Anchoa

Bacalao

Galeos

Rata, puerco marino

Caballito de mar, caballo marino, echenas, hippocampo

Rana marina, rana

Barbo

Merlancio, asellus, asselus, borriquito, asno, bacchus

Merluza

Mújol

Salmonete, mullus, mulus, mulo

Morena, murena

Ophidion

Coracino

Porquet, peix porquet, peix porc

Erythinus

Perca

Raya

Rémora, odynolites

Trucha

Sarda

Sardina

Corvallo

Rodaballo

Escorpión marino, escorpión marino rojo

Cabracho

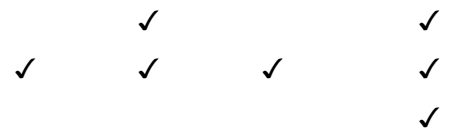

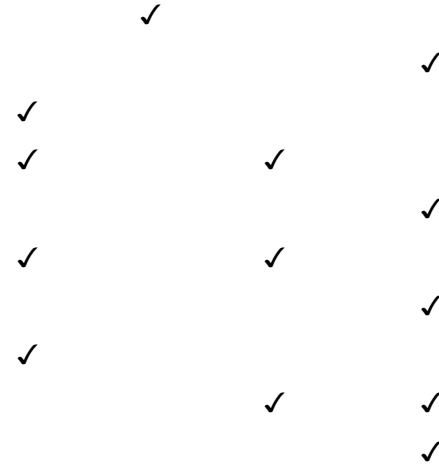

$\checkmark$

$\checkmark$

$\checkmark$

$\checkmark$

$\checkmark$

$\checkmark$

$\checkmark$

$\checkmark$

$\checkmark$

$\checkmark$

$\checkmark$

$\checkmark$

$\checkmark$

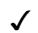

$\checkmark$

$\checkmark$

$\checkmark$

$\checkmark$ 
Table 2 Overview of medically important fish species, indicating the different eras in which they have been used (Continued)

\begin{tabular}{|c|c|c|c|c|c|}
\hline Scyliorhinus canicula (Linnaeus, 1758) & Lija, perro de mar & $\checkmark$ & & & $\checkmark$ \\
\hline Silurus glanis (Linnaeus, 1758) & Siluro, ankala & $\checkmark$ & $\checkmark$ & $\checkmark$ & \\
\hline Solea solea (Linnaeus, 1758) & Lenguado & $\checkmark$ & & $\checkmark$ & \\
\hline Sparisoma cretense (Linnaeus, 1758) & Escaro & $\checkmark$ & & & \\
\hline Sparus aurata Linnaeus, 1758 & Dorada & $\checkmark$ & & & \\
\hline Spicara maena (Linnaeus, 1758) & Mena & $\checkmark$ & & $\checkmark$ & \\
\hline Spicara smaris (Linnaeus, 1758) & Picarel, smarido, caramel & $\checkmark$ & & $\checkmark$ & \\
\hline Squalus acanthias Linnaeus, 1758 & Mielga & & $\checkmark$ & & \\
\hline $\begin{array}{l}\text { Squatina oculata Bonaparte, 1840; S. squatina } \\
\text { (Linnaeus, 1758) }\end{array}$ & Pez angel, angelote & $\checkmark$ & & & $\checkmark$ \\
\hline Thunnus thynnus (Linnaeus, 1758) & $\begin{array}{l}\text { Atún, cybium (tuna under one year), } \\
\text { pelamydes, pelamys (tuna than } \\
\text { one year) }\end{array}$ & $\checkmark$ & & $\checkmark$ & \\
\hline $\begin{array}{l}\text { Torpedo marmorata Risso, 1810; Torpedo torpedo } \\
\text { (Linnaeus, 1758) }\end{array}$ & $\begin{array}{l}\text { Tembladera, torpedo, pez torpedo, } \\
\text { trimilga }\end{array}$ & $\checkmark$ & & $\checkmark$ & \\
\hline Trachinus draco Linnaeus, 1758 & Araña, araña de mar, dragón marino & $\checkmark$ & & $\checkmark$ & \\
\hline Trachinus radiatus Cuvier, 1829 & Escorpión, escorpión de mar & $\checkmark$ & & & \\
\hline Trachurus trachurus (Linnaeus, 1758) & Jurel & $\checkmark$ & & & \\
\hline Trigla lyra Linnaeus, 1758 & Trigla, triga & $\checkmark$ & $\checkmark$ & & \\
\hline Trigloporus lastoviza (Bonnaterre, 1788) & Rubio, al-santara & & $\checkmark$ & & \\
\hline Uranoscopus scaber Linnaeus, 1758 & Pez rata & $\checkmark$ & & & \\
\hline
\end{tabular}

\section{On the determination of the species}

There is no doubt that the identification of species that appear in historical and classical works is inherently difficult. In relation to this problem on taxonomic interpretation Josefa Cantó writes:

"The difficulties are varied: scarcity and inconsistency of data-often saying incompatible things about the same species in different-passages; even Pliny makes mistakes, sometimes he misinterprets his sources and combines names and characteristics that do not correspond to the same species. It contributes to the confusion that sometimes he uses two different names, one Greek and one Latin, for the same fish. Besides data from ancient texts about size, colour, habitat, habits, etc., the etymology of the names or their possible survival in Romance languages may help. It's important to enlist the help of biologists since their knowledge of marine species allows a better guess at what may lay hidden behind a superficial description" [26].

We include some fragments of the work by Francisco Vélez de Arciniega published in 1613, entitled Historia de los animales mas recebidos en el uso de medicina: donde se trata para lo que cada uno entero ò parte del aprovecha y de la manera de su preparacion..., which has been useful to make a differential diagnosis of some species. This work is of special interest because it synthesizes descriptions of Aristotle, Dioscorides, Pliny and Galen, among other classic authors.

In the fourth book De los pescados recebidos en el uso de la Medicina, Vélez de Arciniega "De las Menas" and "Del Smarido" tells us that:

"Menas are very similar to Smaridos, which (according to Pliny) change colour at different times of the year, and are white in the winter and black in the summer. They swim collectively in the sea, near the shore" [36].

The differential diagnosis leads to Spicara maena and S. smaris. The "mena" is $S$. maena, which presents a very variable coloration according to sex, age and season. Spicara smaris, the "smarido", unlike which has a silvery, gray back and as the text indicates swims in important shoals.

"Del Gobio" we get Crystallogobius linearis:

"It is a small fish the gobio, which has a big mouth in proportion to the body: belly it has many strands close to its belly, it is glutinous: and so very easily be slips between the hands. According to Aelianus: The Gobio, Dragon and Sea Swallow, pitch poison, but it is not fatal ... They lay (according to Aristotle) their eggs on the banks, against the stones and in the sands" [36]. 
Table 3 List of Spanish traditional remedies based on the use of fish

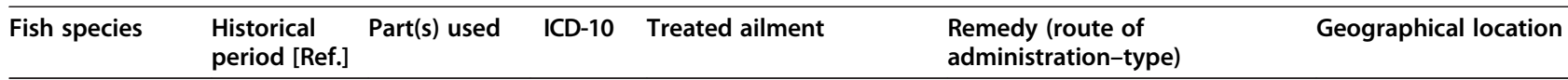

\begin{tabular}{|c|c|c|c|c|c|c|}
\hline \multirow[t]{3}{*}{ Acipenser sturio } & MED [34] & Meat & I & Rabies & It is useful for rabid dog bite (?) & - \\
\hline & MED [34] & Meat & $X X$ & $\begin{array}{l}\text { Bite and stings from } \\
\text { venomous animals }\end{array}$ & $\begin{array}{l}\text { "If a person who has been bitten } \\
\text { by a snake eats the crocodile like } \\
\text { fish and then drinks wine vomits, } \\
\text { this is good and will save them } \\
\text { from death. This fish is useful for } \\
\text { bites from the horned viper and } \\
\text { those of scorpions and } \\
\text { salamanders. If the sea hare is } \\
\text { crushed in vinegar and applied } \\
\text { this also relieves pain" (IN-EMP) }\end{array}$ & - \\
\hline & CON [77] & $\begin{array}{l}\text { Swim } \\
\text { bladder }\end{array}$ & $X I I I$ & Lumbago & $\begin{array}{l}\text { Give massages with fish jelly. The } \\
\text { higher quality gelatin is obtained } \\
\text { from the swim bladder of this } \\
\text { species (EX-EMP) }\end{array}$ & Doñana (Andalusia) \\
\hline \multirow[t]{12}{*}{ Anguilla anguilla } & ANC [26] & $\begin{array}{l}\text { Whole } \\
\text { animal }\end{array}$ & V & Alcoholism & $\begin{array}{l}\text { The drink resulting from } \\
\text { drowning two eels in wine ... } \\
\text { will cause rejection of wine in } \\
\text { those who drink it (IN-EMP) }\end{array}$ & - \\
\hline & ANC [29] & Blood & V & Drunkenness (inebriation) & $\begin{array}{l}\text { To remove drunkenness, it is } \\
\text { necessary to prepare a potion } \\
\text { with wine and three drops of } \\
\text { blood of eel, uttering magic } \\
\text { words, in relation to the } \\
\text { cabalistic numbers } 3,5 \text { and } 7 . \\
\text { Once the drunk has taken this } \\
\text { concoction, he will be free from } \\
\text { drunkenness for the space of } \\
\text { one month (IN-EMP) }\end{array}$ & - \\
\hline & MED [34] & Bile & V & Mental disorders & $\begin{array}{l}\text { Its bile removes madness when it } \\
\text { is inhaled (IN-EMP) }\end{array}$ & - \\
\hline & MED [34] & - & $X I$ & Liver pain & - & - \\
\hline & MED [34] & - & XIV & Aphrodisiac & - & - \\
\hline & MED [34] & - & $X V I I I$ & Jaundice (unspecified) & - & - \\
\hline & MDR [35] & $\begin{array}{l}\text { Whole } \\
\text { animal }\end{array}$ & V & Alcoholism & $\begin{array}{l}\text { Those who drink wine in which } \\
\text { eels have been drowned, } \\
\text { develop an aversion to wine } \\
\text { (IN-EMP) }\end{array}$ & - \\
\hline & MDR [36] & $\begin{array}{l}\text { Whole } \\
\text { animal, blood }\end{array}$ & V & Alcoholism & $\begin{array}{l}\text { "This property of making wine to } \\
\text { be hated, attributed to eel, } \\
\text { whenever they are drowned in } \\
\text { wine, or if its blood is added to } \\
\text { it" (IN-EMP) }\end{array}$ & - \\
\hline & MDR [35] & Fat & VIII & Otitis & Its fat cures ears (?) & - \\
\hline & MDR [36] & Fat & VIII & Diseases of the ears & $\begin{array}{l}\text { "Its enxundia (fat), says the book } \\
\text { entitled The Garden of Health, is } \\
\text { used to cure ear diseases" (?) }\end{array}$ & - \\
\hline & CON [68] & Meat & IV & Obesity & $\begin{array}{l}\text { Obesity is prevented those } \\
\text { whose parents ate eels while } \\
\text { they were in the womb } \\
\text { (IN-MAG) }\end{array}$ & $\begin{array}{l}\text { Talarrubias, Peloche, } \\
\text { Herrera del Duque } \\
\text { (Badajoz) }\end{array}$ \\
\hline & CON [53] & Blood & V & Alcoholism & $\begin{array}{l}\text { To cure his vice [of the drunk], } \\
\text { we must make him drink the } \\
\text { blood of eel, without him } \\
\text { knowing. It is thought that } \\
\text { drunkenness is remedied by } \\
\text { drinking eel blood (IN-EMP) }\end{array}$ & Basque Country \\
\hline
\end{tabular}


Table 3 List of Spanish traditional remedies based on the use of fish (Continued)

\begin{tabular}{|c|c|c|c|c|c|c|}
\hline & CON [64] & $\begin{array}{l}\text { Whole } \\
\text { animal }\end{array}$ & V & Alcoholism & $\begin{array}{l}\text { There were those who } \\
\text { introduced a whole eel into the } \\
\text { bottle of wine for them to drink } \\
\text { the liquid [without them } \\
\text { knowing] (IN-EMP) }\end{array}$ & Goizueta (Navarra) \\
\hline & CON [41] & Meat & $X I I I$ & Gout & Eel brine ointments (EX-EMP) & Galicia \\
\hline & CON [52] & Meat & XIII & Gout pain & Brine of eel (EX-EMP) & Galicia \\
\hline & CON $[44,56]$ & Liver & $X V$ & Facilitate delivery & $\begin{array}{l}\text { Eating eel liver is considered } \\
\text { optimal (IN-EMP) }\end{array}$ & Mogarraz (Salamanca) \\
\hline \multirow[t]{4}{*}{$\begin{array}{l}\text { Argyrosomus } \\
\text { regius }\end{array}$} & CON [73] & Otoliths & VII & $\begin{array}{l}\text { Eye diseases and their } \\
\text { prevention }\end{array}$ & $\begin{array}{l}\text { "Piedra de corvina"... a patient } \\
\text { had a stone as a pendant to } \\
\text { protect him/her against the } \\
\text { diseases of the eye (EX-MAG) }\end{array}$ & Province of Palencia \\
\hline & $\operatorname{CON}[42,71]$ & Otoliths & XIV & Sterility & $\begin{array}{l}\text { "Meagre White Stones"... are } \\
\text { considered as a remedy in the } \\
\text { irregularities of pregnancy... } \\
\text { hang (amulet) around the waist } \\
\text { two white stones (EX-MAG) }\end{array}$ & Canary Islands \\
\hline & CON [73] & Otoliths & XIV & Nephropathies & $\begin{array}{l}\text { "Bone amulet: stone basse" ... in } \\
\text { our field work we found that this } \\
\text { fish amulet has preventive } \\
\text { properties and relieve failing } \\
\text { "kidney diseases". We have seen } \\
\text { people wear it as a pendant in } \\
\text { the neck for nephritic diseases } \\
\text { (EX-MAG) }\end{array}$ & Province of Palencia \\
\hline & CON [77] & Otoliths & - & Prophylaxis (in general) & $\begin{array}{l}\text { This "little stone" is usually } \\
\text { carried as a protective amulet. } \\
\text { Although formerly many were } \\
\text { fishermen that had just in the } \\
\text { pocket or in a cloth bag, is now } \\
\text { easier to see set in gold or silver } \\
\text { as a pendant (EX-MAG) }\end{array}$ & Doñana (Andalusia) \\
\hline \multirow[t]{2}{*}{ Brama brama } & MED [30] & Bile & VII & Eye diseases & $\begin{array}{l}\text { Its bile is used in ophthalmic } \\
\text { drugs (IN-EMP) }\end{array}$ & - \\
\hline & MED [34] & Bile & $\mathrm{VII}$ & Eye diseases & $\begin{array}{l}\text { Among the types of fish, the } \\
\text { japuta is balanced. It tends to be } \\
\text { hot, because of its speed of } \\
\text { movement and how much it } \\
\text { jumps. Its bile is more useful for } \\
\text { the eyes than that of other fish, } \\
\text { and so doctors use it as eye } \\
\text { drops. Eye remedies made from } \\
\text { bile refresh the body, especially } \\
\text { in thin people (IN-EMP) }\end{array}$ & - \\
\hline \multirow[t]{2}{*}{$\begin{array}{l}\text { Clupea harengus } \\
\text { harengus }\end{array}$} & CON [43] & Meat & I & Worms & $\begin{array}{l}\text { Cured herring ... which indeed } \\
\text { provides an adjuvant action } \\
\text { (IN-EMP) }\end{array}$ & Basque Country \\
\hline & CON [55] & Meat & $\|$ & Sarcoma & $\begin{array}{l}\text { A family member of my } \\
\text { informant had a leg tumour } \\
\text { removed that quickly returned. } \\
\text { The diagnosis was sarcoma. In } \\
\text { view of this, to cure of this evil it } \\
\text { was recommended that he } \\
\text { made use of a container used for } \\
\text { herrings with several holes in its } \\
\text { base. Introducing two live toads } \\
\text { into the vessel it was closed with } \\
\text { a lid and placed over the } \\
\text { sarcoma, tied in position with a } \\
\text { bandage. If the toads were still } \\
\text { alive the day after having carried } \\
\text { out this procedure, then the }\end{array}$ & Basque Country \\
\hline
\end{tabular}


Table 3 List of Spanish traditional remedies based on the use of fish (Continued)

\begin{tabular}{|c|c|c|c|c|c|c|}
\hline & & & & & $\begin{array}{l}\text { patient could be expected to } \\
\text { recover. However, if the frogs } \\
\text { were dead, it meant the } \\
\text { irreversibility of the disease. In } \\
\text { the house to which I allude, the } \\
\text { toads died (EX-MAG) }\end{array}$ & \\
\hline & CON [54] & Meat & $X V$ & To favour milk production & $\begin{array}{l}\text { Eating herrings in abundance } \\
\text { (IN-EMP) }\end{array}$ & $\begin{array}{l}\text { Castillejo de Robledo } \\
\text { (Soria) }\end{array}$ \\
\hline & CON [43] & $\begin{array}{l}\text { Whole } \\
\text { animal }\end{array}$ & $\mathrm{XVl}$ & $\begin{array}{l}\text { For determining the sex of } \\
\text { an unborn baby }\end{array}$ & $\begin{array}{l}\text { A superstitious practice consist in } \\
\text { put on hot coals a herring, if it } \\
\text { jumps or flips it indicates the } \\
\text { birth of a boy (EX-MAG) }\end{array}$ & Basque Country \\
\hline & CON [51] & Bone & $\mathrm{XVl}$ & $\begin{array}{l}\text { For determining the sex of } \\
\text { an unborn baby }\end{array}$ & $\begin{array}{l}\text { Throwing onto a fire herring } \\
\text { bone to see if it jumps or turns } \\
\text { (EX-MAG) }\end{array}$ & Basque Country \\
\hline Coris julis & ANC [26] & $\begin{array}{l}\text { Whole } \\
\text { animal }\end{array}$ & $X I$ & Laxative & $\begin{array}{l}\text { Broth: releases the bowels. The } \\
\text { best soup is made with sea } \\
\text { scorpions and rainbow wrasse. It } \\
\text { should be cooked with dill, } \\
\text { celery, coriander, leek, oil and salt } \\
\text { (IN-EMP) }\end{array}$ & - \\
\hline \multirow[t]{4}{*}{$\begin{array}{l}\text { Crystallogobius } \\
\text { linearis }\end{array}$} & ANC [27] & $\begin{array}{l}\text { Whole } \\
\text { animal }\end{array}$ & $X I$ & Laxative & $\begin{array}{l}\text { Fresh goby, if you put it into the } \\
\text { belly of a pig, sew up well and } \\
\text { cook in } 12 \text { sextarios [ } 6.5 \text { litres] of } \\
\text { water until they are reduced to } \\
\text { two, and then let to cool } \\
\text { outdoors and drink it, will empty } \\
\text { your bowels without discomfort } \\
\text { (IN-EMP) }\end{array}$ & - \\
\hline & ANC [27] & $\begin{array}{l}\text { Whole } \\
\text { animal }\end{array}$ & $x X$ & Dog and snake bites & $\begin{array}{l}\text { Applied as a poultice also } \\
\text { benefits those bitten (EX-EMP) }\end{array}$ & - \\
\hline & MDR [36] & Meat & $X I$ & Relaxing the belly & $\begin{array}{l}\text { "He remembers Dioscorides } \\
\text { saying: If you put one goby in } \\
\text { the stomach of a dog, and sew it } \\
\text { up then in twelve parts of water } \\
\text { boiled until two, the cooled } \\
\text { liquid will, relax the belly without } \\
\text { any pain" (IN-EMP) }\end{array}$ & - \\
\hline & MDR [36] & Meat & $X X$ & Dog and snake bites & $\begin{array}{l}\text { "Applied externally it is also } \\
\text { helpful for those who have been } \\
\text { wounded by snake, or by dogs" } \\
\text { (EX-EMP) }\end{array}$ & - \\
\hline \multirow[t]{2}{*}{ Cyprinus carpio } & CONT [71] & Bile & I & Erysipelas & $\begin{array}{l}\text { An excellent remedy for } \\
\text { erysipelas is the sweetly } \\
\text { anointing with a feather dipped } \\
\text { in the bile of carp... putting on } \\
\text { top a clean, dry cloth (EX-EMP) }\end{array}$ & Canary Islands \\
\hline & CONT [77] & $\begin{array}{l}\text { Bone, swim } \\
\text { bladder and } \\
\text { other } \\
\text { leftovers }\end{array}$ & XIII & Lumbago & $\begin{array}{l}\text { Give rubs with jelly fish, obtained } \\
\text { from cooking the bones and } \\
\text { other debris from these fish } \\
\text { (EX-EMP) }\end{array}$ & Doñana (Andalusia) \\
\hline \multirow[t]{3}{*}{$\begin{array}{l}\text { Dasyatis } \\
\text { pastinaca }\end{array}$} & ANC [26] & Sting & । & Scrofulous tumours & $\begin{array}{l}\text { It is good to lance scrofulous } \\
\text { tumours, so that there is no } \\
\text { wound, with the sting of the } \\
\text { stingray, it must be done daily } \\
\text { until it is healed completely } \\
\text { (EX-EMP) }\end{array}$ & - \\
\hline & ANC [26] & Sting & $X \mid$ & Toothache & $\begin{array}{l}\text { Scarifying the gums with the } \\
\text { sting sooths them (EX-EMP) }\end{array}$ & - \\
\hline & ANC [27] & Sting & $X \mid$ & Toothache & $\begin{array}{l}\text { The sting soothes toothaches, } \\
\text { making the teeth fall out } \\
\text { (EX-EMP) }\end{array}$ & - \\
\hline
\end{tabular}


Table 3 List of Spanish traditional remedies based on the use of fish (Continued)

\begin{tabular}{|c|c|c|c|c|c|c|}
\hline & ANC [26] & Liver & $X I I$ & $\begin{array}{l}\text { Skin diseases (lichen, } \\
\text { exfoliative dermatitis) }\end{array}$ & $\begin{array}{l}\text { Seal fat removes lichen and } \\
\text { exfoliative dermatitis, with three } \\
\text { óbolos of honey, a stingray liver } \\
\text { cooked in oil and the ashes of a } \\
\text { sea horse or dolphin applied } \\
\text { with water. The treatment, which } \\
\text { causes scaring, should be applied } \\
\text { after excoriation (EX-EMP) }\end{array}$ & - \\
\hline & ANC [26] & Sting & $X V$ & Facilitate delivery & $\begin{array}{l}\text { The sting applied to the navel, if } \\
\text { taken from a live ray the tossed } \\
\text { back into the sea (EX-MAG) }\end{array}$ & - \\
\hline & ANC [26] & $\begin{array}{l}\text { Whole } \\
\text { animal }\end{array}$ & $X X$ & Antidote & $\begin{array}{l}\text { It is its own sting remedy, } \\
\text { applied as ash, or another ray } \\
\text { with vinegar (EX-EMP) }\end{array}$ & - \\
\hline & MDR [36] & Sting & $X I$ & Toothache & $\begin{array}{l}\text { "The sting in the tail of the } \\
\text { stingray located between the } \\
\text { scales pushed up between teeth, } \\
\text { mitigates the pain of the teeth, } \\
\text { making them fall" (EX-EMP) }\end{array}$ & - \\
\hline $\begin{array}{l}\text { Dicologoglossa } \\
\text { cuneata }\end{array}$ & CON [77] & Meat & $X V$ & As galactagogue & $\begin{array}{l}\text { It is suggested the consumption } \\
\text { of this fish to improve breast } \\
\text { milk production (IN-EMP) }\end{array}$ & Doñana (Andalusia) \\
\hline Dipturus batis & ANC [26] & Bile & VIII & Ear diseases & $\begin{array}{l}\text { Fresh bile is very good for the } \\
\text { ears, but also preserved in wine } \\
\text { (IN-EMP) }\end{array}$ & - \\
\hline \multirow[t]{3}{*}{$\begin{array}{l}\text { Engraulis } \\
\text { encrasicolus }\end{array}$} & MDR [35] & $\begin{array}{l}\text { Whole } \\
\text { animal }\end{array}$ & 1 & Scabies & $\begin{array}{l}\text { If it is introduced through cut } \\
\text { skin, chest scabies is cured with } \\
\text { anchovy (IN-EMP) }\end{array}$ & - \\
\hline & MDR [35] & - & $X X$ & Bites & $\begin{array}{l}\text { It is good against dog bite or sea } \\
\text { dragon (?) }\end{array}$ & - \\
\hline & CON [70] & Meat & IX & Low blood pressure & $\begin{array}{l}\text { Eating salty foods: anchovies } \\
\text { (IN-EMP) }\end{array}$ & La Aparecida (Alicante) \\
\hline \multirow[t]{12}{*}{ Gadus morhua } & CON [70] & Meat & I & Tapeworm (infection) & $\begin{array}{l}\text { Take cod and lots of water } \\
\text { (IN-EMP) }\end{array}$ & La Aparecida (Alicante) \\
\hline & CON [50] & Liver & III & Nutritional anaemia & Take cod liver oil (IN-EMP) & $\begin{array}{l}\text { Alba de Tormes, Cabeza } \\
\text { de Béjar (Salamanca) }\end{array}$ \\
\hline & $\mathrm{CON}[46]$ & Liver & IV & $\begin{array}{l}\text { Loss of appetite } \\
\text { (malnutrition) }\end{array}$ & $\begin{array}{l}\text { As a dietary supplement, the } \\
\text { most common and popular, ... is } \\
\text { the cod liver oil (a few } \\
\text { tablespoons) (IN-EMP) }\end{array}$ & Villena (Alicante) \\
\hline & CON [64] & Liver & IV & Work up an appetite & $\begin{array}{l}\text { To return appetite to those who } \\
\text { lost it cod liver oil was given } \\
\text { (IN-EMP) }\end{array}$ & $\begin{array}{l}\text { Basque Country, } \\
\text { Navarra }\end{array}$ \\
\hline & CON [69] & Meat & IV & Open appetite & Eaten (IN-EMP) & $\begin{array}{l}\text { Guadiana del Caudillo } \\
\text { (Badajoz) }\end{array}$ \\
\hline & CON [74] & Liver & IV & Lack of appetite & $\begin{array}{l}\text { The cod liver oil was taken as a } \\
\text { tonic (IN-EMP) }\end{array}$ & $\begin{array}{l}\text { Comarca de Campoo } \\
\text { (Cantabria) }\end{array}$ \\
\hline & CON [64] & Liver & IV & Rickets & $\begin{array}{l}\text { Some locations underscore the } \\
\text { importance of taking cod liver oil } \\
\text { (IN-EMP) }\end{array}$ & $\begin{array}{l}\text { Basque Country, } \\
\text { Navarra }\end{array}$ \\
\hline & CON [70] & Liver & IV & Food for strength & Iron and cod liver oil (IN-EMP) & La Aparecida (Alicante) \\
\hline & CON [75] & Liver & IV & Take strength, restorative & $\begin{array}{l}\text { Cod liver oil... taken as food } \\
\text { (IN-EMP) }\end{array}$ & $\begin{array}{l}\text { Fuente de Cantos } \\
\text { (Badajoz) }\end{array}$ \\
\hline & CON [70] & Meat & IX & $\begin{array}{l}\text { Low blood pressure } \\
\text { (hypotension) }\end{array}$ & $\begin{array}{l}\text { Eating foods high in salt: cod... } \\
\text { (IN-EMP) }\end{array}$ & La Aparecida (Alicante) \\
\hline & CON [64] & Liver & IX & $\begin{array}{l}\text { St. Vitus Dance (Sydenham } \\
\text { chorea or chorea minor) }\end{array}$ & $\begin{array}{l}\text { Cod liver oil is given to the sick } \\
\text { (IN-EMP) }\end{array}$ & Abadiano (Biscay) \\
\hline & CON [78] & Liver & $x$ & Antitussive & Cod liver oil, syrup (IN-EMP) & \\
\hline
\end{tabular}


Table 3 List of Spanish traditional remedies based on the use of fish (Continued)

\begin{tabular}{|c|c|c|c|c|c|c|}
\hline & & & & & & $\begin{array}{l}\text { Eastern Catalan } \\
\text { Pyrenees }\end{array}$ \\
\hline & CON [76] & Maxillary & $X I$ & Baby toothache & $\begin{array}{l}\text { The "gaia" of cod (jawbone), that } \\
\text { many children wear around their } \\
\text { necks, is gnawed like a dummy } \\
\text { to relive teething pain (IN-EMP) }\end{array}$ & Catalonia \\
\hline & CON [46] & Maxillary & $X I$ & $\begin{array}{l}\text { Encourage good dentition } \\
\text { in children }\end{array}$ & $\begin{array}{l}\text { They gave the child a jawbone } \\
\text { of cod to bite, "hueso de } \\
\text { bacalao" (IN-EMP) }\end{array}$ & $\begin{array}{l}\text { Busot (Alicante); Castillo } \\
\text { de Villamafela } \\
\text { (Castellón); Adamuz, } \\
\text { Aras de Alpuente, Villar } \\
\text { del Arzobispo (Valencia) }\end{array}$ \\
\hline & CON [59] & Tooth & $X I$ & $\begin{array}{l}\text { Encourage good dentition } \\
\text { in children }\end{array}$ & $\begin{array}{l}\text { Use a good cod tooth with a } \\
\text { hole made in it and hung by a } \\
\text { ribbon around the neck, biting } \\
\text { that tooth was a good remedy } \\
\text { to prevent and ensure good } \\
\text { teeth (IN-EMP) }\end{array}$ & Valencia \\
\hline & CON [64] & Jaw, fins & $X I$ & $\begin{array}{l}\text { Encourage good dentition } \\
\text { in children }\end{array}$ & $\begin{array}{l}\text { They gave the child a jawbone } \\
\text { of cod to bite, or the round part } \\
\text { of the fin in dried cod (IN-EMP) }\end{array}$ & $\begin{array}{l}\text { Basque Country, } \\
\text { Navarra }\end{array}$ \\
\hline & CON [72] & Gills & $X I$ & $\begin{array}{l}\text { Encourage good dentition } \\
\text { in children }\end{array}$ & $\begin{array}{l}\text { To relieve the pain of first teeth } \\
\text { coming out, a cod gill was given } \\
\text { to the child to bite (IN-EMP) }\end{array}$ & $\begin{array}{l}\text { La Vall d’Uixó } \\
\text { (Castellón) }\end{array}$ \\
\hline & CON [43] & $\begin{array}{l}\text { Meat, whole } \\
\text { animal }\end{array}$ & $X V$ & $\begin{array}{l}\text { Stimulate the secretion of } \\
\text { milk (galactagogue) }\end{array}$ & $\begin{array}{l}\text { To ensure abundant production } \\
\text { of milk from the breast, intake of } \\
\text { fried cod or cod broth are } \\
\text { empirically recommended } \\
\text { (IN-EMP) }\end{array}$ & Basque Country \\
\hline & CON [49] & Meat & $X V$ & $\begin{array}{l}\text { Stimulate the secretion of } \\
\text { milk (galactagogue) }\end{array}$ & Eat salads with cod (IN-EMP) & $\begin{array}{l}\text { Comarca de El Rebollar } \\
\text { (Salamanca) }\end{array}$ \\
\hline & CON [67] & Meat & $X V$ & $\begin{array}{l}\text { Stimulate the secretion of } \\
\text { milk (galactagogue) }\end{array}$ & $\begin{array}{l}\text { Eat this fish induces liquid intake } \\
\text { and produces milk (IN-EMP) }\end{array}$ & $\begin{array}{l}\text { Campo de Cartagena } \\
\text { (Murcia) }\end{array}$ \\
\hline & CON [43] & Meat & XIX & Seasickness & $\begin{array}{l}\text { Habit of chewing salted cod ... } \\
\text { is usual in our fishermen, at the } \\
\text { first sign of imbalance, which } \\
\text { even they are not immune } \\
\text { (IN-EMP) }\end{array}$ & Basque Country \\
\hline & CON [62] & Meat & XIX & Seasickness & $\begin{array}{l}\text { Taking a piece of salted cod to } \\
\text { be taken, from time to time, a } \\
\text { fragment is inserted into the } \\
\text { mouth and is consumed slowly } \\
\text { (IN-EMP) }\end{array}$ & Basque Country \\
\hline & CON [70] & Liver & XIX & Hunger (effects) & Cod liver oil (IN-EMP) & La Aparecida (Alicante) \\
\hline & CON [64] & Liver & $X X I$ & Convalescence & Given to the sick (IN-EMP) & Abadiano (Biscay) \\
\hline $\begin{array}{l}\text { Galeorhinus } \\
\text { galeus }\end{array}$ & ANC [26] & - & $X X$ & Antidote & Cures those stung by stingray(?) & - \\
\hline \multirow[t]{2}{*}{$\begin{array}{l}\text { Halobatrachus } \\
\text { didactylus }\end{array}$} & ANC [26] & - & $X X$ & Antidote & $\begin{array}{l}\text { Among the poisonous parts of } \\
\text { fish is the puerco marino dorsal } \\
\text { spine, causing great pain to } \\
\text { those affected, the remedy is the } \\
\text { "silt" collected from the rest of } \\
\text { the body of this fish (?) }\end{array}$ & - \\
\hline & CON [48] & Liver & I & $\begin{array}{l}\text { Chest infections, when it is } \\
\text { expected to be open to } \\
\text { having to take all the pus }\end{array}$ & $\begin{array}{l}\text { Put the liver on the top of the } \\
\text { boiler of the ship, slowly } \\
\text { obtaining a large amount of oil } \\
\text { of that liver, called "rat oil". } \\
\text { Another way to obtain it is with } \\
\text { the same operation but cooking } \\
\text { the livers in a pot where it will } \\
\text { melt to get rat oil. The oil is used }\end{array}$ & Galicia \\
\hline
\end{tabular}


Table 3 List of Spanish traditional remedies based on the use of fish (Continued)

\begin{tabular}{|c|c|c|c|c|c|c|}
\hline & & & & & $\begin{array}{l}\text { even when healing is well under } \\
\text { way (EX-EMP) }\end{array}$ & \\
\hline \multirow[t]{14}{*}{$\begin{array}{l}\text { Hippocampus } \\
\text { hippocampus; } \\
\text { H. guttulatus }\end{array}$} & ANC [28] & $\begin{array}{l}\text { Whole } \\
\text { animal }\end{array}$ & I & Rabies & $\begin{array}{l}\text { One roasted them and gave } \\
\text { them to the sick so that they are } \\
\text { taken and others mashed in } \\
\text { vinegar and honey, and thus } \\
\text { made into a poultice and applied } \\
\text { to the bite wounds, and the } \\
\text { result of this operation was that } \\
\text { the rabies was dominated in } \\
\text { young people, given the desire } \\
\text { for water caused in them by the } \\
\text { seahorses (IN/EX-EMP) }\end{array}$ & - \\
\hline & ANC [26] & $\begin{array}{l}\text { Whole } \\
\text { animal }\end{array}$ & V & Urinary incontinence & $\begin{array}{l}\text { Roasted and taken with food, } \\
\text { they heal urinary incontinence } \\
\text { (IN-EMP) }\end{array}$ & - \\
\hline & ANC [27] & $\begin{array}{l}\text { Whole } \\
\text { animal }\end{array}$ & $X \|$ & Alopecia & $\begin{array}{l}\text { Whose ashes ... once burned, } \\
\text { mixed with liquid pine resin or } \\
\text { pig lard or marjoram perfume } \\
\text { and applied as an ointment, it } \\
\text { makes hair sprout on bald } \\
\text { patches (EX-EMP) }\end{array}$ & - \\
\hline & ANC [26] & $\begin{array}{l}\text { Whole } \\
\text { animal }\end{array}$ & $X \|$ & Dermatitis & Ash (?) & - \\
\hline & ANC [26] & $\begin{array}{l}\text { Whole } \\
\text { animal }\end{array}$ & XIII & Rib pains & Roasted (IN-EMP) & - \\
\hline & ANC [26] & $\begin{array}{l}\text { Whole } \\
\text { animal }\end{array}$ & $X V I I I$ & Fever & $\begin{array}{l}\text { Drown seahorses in rose oil to } \\
\text { anointing the sick with cold } \\
\text { fevers, and placed as amulets on } \\
\text { the sick (EX-MAG) }\end{array}$ & - \\
\hline & ANC [26] & $\begin{array}{l}\text { Whole } \\
\text { animal }\end{array}$ & $X X$ & Antidote & $\begin{array}{l}\text { It counteracts the poison of sea } \\
\text { hare (?) }\end{array}$ & - \\
\hline & MDR [35] & Skin & 1 & Scabies & $\begin{array}{l}\text { Its raw skin is useful for scabies, } \\
\text { when mixed with other } \\
\text { medicines (EX-EMP) }\end{array}$ & - \\
\hline & MDR [35] & $\begin{array}{l}\text { Whole } \\
\text { animal }\end{array}$ & $X I$ & Diarrhoea & $\begin{array}{l}\text { Burned alive and drunk with } \\
\text { sweet wine, cures diarrhoea } \\
\text { (IN-EMP) }\end{array}$ & - \\
\hline & MDR [35] & Meat & $X I$ & Stomach pains & $\begin{array}{l}\text { Dioscorides: The taste of the } \\
\text { seahorse is good for the } \\
\text { stomach, calms the tummy and } \\
\text { is diaphoretic (IN-EMP) }\end{array}$ & - \\
\hline & MDR [35] & $\begin{array}{l}\text { Whole } \\
\text { animal }\end{array}$ & $X \|$ & Alopecia & $\begin{array}{l}\text { Seahorse ash burned with all the } \\
\text { meat and oil, restores baldness } \\
\text { (EX-EMP) }\end{array}$ & - \\
\hline & MDR [36] & $\begin{array}{l}\text { Whole } \\
\text { animal }\end{array}$ & $X \|$ & Alopecia & $\begin{array}{l}\text { "As Dioscorides said: A small } \\
\text { marine animal, is the } \\
\text { Hippocampo, whose ashes } \\
\text { mixed with wet pine resin or fat, } \\
\text { applied as an ointment, will } \\
\text { make hair return to wherever is } \\
\text { bald" (EX-EMP) }\end{array}$ & - \\
\hline & MDR [35] & Heads & $X \|$ & $\begin{array}{l}\text { Chloasma (mask of } \\
\text { pregnancy) }\end{array}$ & $\begin{array}{l}\text { Crushed and administered with } \\
\text { water in the form of ointment, it } \\
\text { stops the appearance of patches } \\
\text { (EX-EMP) }\end{array}$ & - \\
\hline & MDR [35] & $\begin{array}{l}\text { Whole } \\
\text { animal }\end{array}$ & $\mathrm{XV}$ & Avoid deliveries developed & $\begin{array}{l}\text { The seahorse if pregnant women } \\
\text { wear them as charms up to the } \\
\text { time of delivery, prevents early } \\
\text { births, for this it is preserved in } \\
\text { salt (EX-MAG) }\end{array}$ & - \\
\hline
\end{tabular}


Table 3 List of Spanish traditional remedies based on the use of fish (Continued)

\begin{tabular}{|c|c|c|c|c|c|c|}
\hline & MDR [35] & $\begin{array}{l}\text { Whole } \\
\text { animal }\end{array}$ & XIV & Kidney stones & $\begin{array}{l}\text { Crushed with thorns and drunk } \\
\text { in wine, they remove kidney } \\
\text { stones, sometimes given as solid } \\
\text { food (IN-EMP) }\end{array}$ & - \\
\hline & MDR [35] & Skin & $X I X$ & Wounds & $\begin{array}{l}\text { Burnt, it cleans infected wounds } \\
\text { and stops worsening (EX-EMP) }\end{array}$ & - \\
\hline & MDR [35] & $\begin{array}{l}\text { Whole } \\
\text { animal }\end{array}$ & $X I X$ & Poisoning & $\begin{array}{l}\text { This same fish, retains the belly, } \\
\text { for which seahorses are very } \\
\text { good against dorycnium (poison) } \\
\text { (IN-EMP) }\end{array}$ & - \\
\hline & CON [40] & $\begin{array}{l}\text { Whole } \\
\text { animal }\end{array}$ & I & Erysipelas & $\begin{array}{l}\text { Amulet: wear a seahorse } \\
\text { (hippocampus) as a necklace } \\
\text { (EX-MAG) }\end{array}$ & $\begin{array}{l}\text { Province of Badajoz } \\
\text { (near Sierra de Aracena) }\end{array}$ \\
\hline & CON [47] & $\begin{array}{l}\text { Whole } \\
\text { animal }\end{array}$ & $X I$ & Toothache & $\begin{array}{l}\text { "They dried seahorses in the } \\
\text { pocket because they say } \\
\text { toothache cure" (EX-MAG) }\end{array}$ & Aragon \\
\hline & CON [66] & $\begin{array}{l}\text { Whole } \\
\text { animal }\end{array}$ & $X I$ & Toothache & $\begin{array}{l}\text { Carry dried seahorses in your } \\
\text { pocket because it is said that } \\
\text { they cure toothache (EX-MAG) }\end{array}$ & Province of Huelva \\
\hline & CON [45] & $\begin{array}{l}\text { Whole } \\
\text { animal }\end{array}$ & $X V I I I$ & Headache & - & Levantine area \\
\hline $\begin{array}{l}\text { Lophius } \\
\text { piscatorius }\end{array}$ & ANC [26] & $\begin{array}{l}\text { Whole } \\
\text { animal, heart }\end{array}$ & 1 & Dysentery & $\begin{array}{l}\text { Marine frogs cooked with sea } \\
\text { squill, so as to make pills, or their } \\
\text { hearts macerated with honey } \\
\text { (IN-EMP) }\end{array}$ & - \\
\hline & ANC [26] & Bone & I & Scrofulosis & $\begin{array}{l}\text { Pricking is good for scrofulous } \\
\text { tumours, so that there is no } \\
\text { wound, with a small tail bone of } \\
\text { the marine fish called "frog", it } \\
\text { should be done daily until it is } \\
\text { completely healed (EX-EMP) }\end{array}$ & - \\
\hline & ANC [26] & $\begin{array}{l}\text { Whole } \\
\text { animal }\end{array}$ & I & Tetanus & $\begin{array}{l}\text { Drinking marine frog broth } \\
\text { cooked in oil with salt. For those } \\
\text { who have spasms we must add } \\
\text { pepper (IN-EMP) }\end{array}$ & - \\
\hline & ANC [26] & $\begin{array}{l}\text { Whole } \\
\text { animal }\end{array}$ & $x$ & Tonsils (enlargement) & $\begin{array}{l}\text { Marine frog broth cooked in } \\
\text { vinegar (IN-EMP) }\end{array}$ & - \\
\hline & ANC [26] & $\begin{array}{l}\text { Whole } \\
\text { animal }\end{array}$ & $X \|$ & Skin conditions & $\begin{array}{l}\text { Cooked in seawater. It should be } \\
\text { cooked until it reaches the } \\
\text { consistency of honey (IN-EMP) }\end{array}$ & - \\
\hline & ANC [26] & Bile & XII & $\begin{array}{l}\text { Malignant ulcers, corrosive } \\
\text { and rotten }\end{array}$ & $\begin{array}{l}\text {... worms growing in them are } \\
\text { removed with marine frog gall } \\
\text { (EX-EMP) }\end{array}$ & - \\
\hline & ANC [26] & $\begin{array}{l}\text { Whole } \\
\text { animal }\end{array}$ & $X I I I$ & Stiff neck & $\begin{array}{l}\text { Drinking marine frog broth } \\
\text { cooked in oil with salt (IN-EMP) }\end{array}$ & - \\
\hline & ANC [26] & Entrails & $X I I I$ & Gout and joint diseases & $\begin{array}{l}\text { Oil in which marine frog bowels } \\
\text { are cooked (EX-EMP) }\end{array}$ & - \\
\hline & ANC [26] & $\begin{array}{l}\text { Whole } \\
\text { animal }\end{array}$ & $X I I I$ & Arthritis & $\begin{array}{l}\text { Fresh marine frog calms arthritis } \\
\text { attacks, some apply the frogs } \\
\text { opened (EX-EMP) }\end{array}$ & - \\
\hline & ANC [26] & Fat & $X V I I I$ & Headache & $\begin{array}{l}\text { Marine frog fat poured drop by } \\
\text { drop takes the pain away } \\
\text { (EX-EMP) }\end{array}$ & - \\
\hline
\end{tabular}


Table 3 List of Spanish traditional remedies based on the use of fish (Continued)

\begin{tabular}{|c|c|c|c|c|c|c|}
\hline & ANC [26] & Meat & $X X$ & Antidote & $\begin{array}{l}\text { Marine frog broth cooked in } \\
\text { wine and vinegar is drunk } \\
\text { against poisons; ... If you eat the } \\
\text { meat it is also useful against sea } \\
\text { hare and against snakes } \\
\text { mentioned above also against } \\
\text { scorpions, boiled with wine } \\
\text { (IN-EMP) }\end{array}$ & - \\
\hline $\begin{array}{l}\text { Luciobarbus } \\
\text { sclateri }\end{array}$ & CONT [77] & $\begin{array}{l}\text { Bone, swim } \\
\text { bladder and } \\
\text { other } \\
\text { leftovers }\end{array}$ & $X I I I$ & Lumbago & $\begin{array}{l}\text { Give rubs with jelly fish, obtained } \\
\text { from cooking the bones and } \\
\text { other debris from these fish } \\
\text { (EX-EMP) }\end{array}$ & Doñana (Andalusia) \\
\hline \multirow[t]{4}{*}{$\begin{array}{l}\text { Merlangius } \\
\text { merlangus }\end{array}$} & ANC [26] & Bile & VIII & Ear diseases & $\begin{array}{l}\text { For the ears fresh bile is very } \\
\text { good, but also preserved in wine } \\
\text { (IN-EMP) }\end{array}$ & - \\
\hline & ANC [26] & Otoliths & XIV & Kidney stones & $\begin{array}{l}\text { In the head of bacchus there are } \\
\text { a kind of stone, which swallowed } \\
\text { with water are very good for } \\
\text { those who have kidney stones } \\
\text { (IN-EMP) }\end{array}$ & - \\
\hline & ANC [26] & Otoliths & $X \mathrm{~V} I I I$ & Fever & $\begin{array}{l}\text { Also the small stones found in } \\
\text { the head of the asellus, during a } \\
\text { full moon is hung in a washcloth } \\
\text { as an amulet (EX-MAG) }\end{array}$ & - \\
\hline & MDR [38] & Otoliths & XIV & Renal colic, kidney stones & $\begin{array}{l}\text { Make a fine powder, and grind } \\
\text { down crab eyes, the stones of } \\
\text { Perches Fish, and Merlancio: Take } \\
\text { the blood of Macho, Millet and } \\
\text { mealybugs, and add and store } \\
\text { for use. They are appropriate for } \\
\text { kidney stones, for sands, for } \\
\text { nephritic colic, and to excite the } \\
\text { urine. Its dosage is half a scruple } \\
\text { to a dragma (IN-EMP) }\end{array}$ & - \\
\hline $\begin{array}{l}\text { Merluccius } \\
\text { merluccius }\end{array}$ & CON [62] & Liver & IX & Cardiac pathologies & $\begin{array}{l}\text { It is food that is considered very } \\
\text { good for the heart, and is } \\
\text { recommended to those with } \\
\text { cardiac pathology... it is usually } \\
\text { eaten fried (IN-EMP) }\end{array}$ & Basque Country \\
\hline \multirow[t]{2}{*}{ Mugil cephalus } & ANC [26] & Head & $X I$ & Chafing of the anus & $\begin{array}{l}\text { Cured with the ash of mullet } \\
\text { heads (EX-EMP) }\end{array}$ & - \\
\hline & MDR [35] & Head & $X I I I$ & Sciatica & $\begin{array}{l}\text { The ash of the head cures } \\
\text { (EX-EMP) }\end{array}$ & - \\
\hline \multirow[t]{5}{*}{$\begin{array}{l}\text { Mullus barbatus } \\
\text { barbatus; } \\
\text { M. surmuletus }\end{array}$} & ANC [26] & $\begin{array}{l}\text { Whole } \\
\text { animal }\end{array}$ & V & Alcoholism & $\begin{array}{l}\text { The resulting drink from } \\
\text { drowning a goatfish, ... and } \\
\text { also from marinated sea grape, } \\
\text { causes a rejection of wine in } \\
\text { those who drink it (IN-EMP) }\end{array}$ & - \\
\hline & ANC [26] & $\begin{array}{l}\text { Whole } \\
\text { animal, meat }\end{array}$ & $X I$ & Indigestion & $\begin{array}{l}\text { Rubbed or taken in food } \\
\text { (IN/EX-EMP) }\end{array}$ & - \\
\hline & ANC [26] & $\begin{array}{l}\text { Whole } \\
\text { animal }\end{array}$ & $X I$ & Induce vomiting & $\begin{array}{l}\text { Preserved, crushed and mixed } \\
\text { with drinking (IN-EMP) }\end{array}$ & - \\
\hline & ANC [26] & $\begin{array}{l}\text { Whole } \\
\text { animal, head }\end{array}$ & $X \|$ & Carbuncle & $\begin{array}{l}\text { Gets rid of carbuncles rid ... the } \\
\text { ash of salting goatfish -some use } \\
\text { only the head with honey- } \\
\text { (EX-EMP) }\end{array}$ & - \\
\hline & ANC [26] & $\begin{array}{l}\text { Whole } \\
\text { animal, meat }\end{array}$ & $X X$ & Antidote & $\begin{array}{l}\text { Against falangia (reaper), marine } \\
\text { dragons and land scorpions. } \\
\text { Rubbed or taken in food } \\
\text { (IN/EX-EMP) }\end{array}$ & - \\
\hline
\end{tabular}


Table 3 List of Spanish traditional remedies based on the use of fish (Continued)

\begin{tabular}{|c|c|c|c|c|c|c|}
\hline & ANC [26] & $\begin{array}{l}\text { Whole } \\
\text { animal, meat }\end{array}$ & $X X$ & Antidote & $\begin{array}{l}\text { It cures those stung by the } \\
\text { stingray. Rubbed in or taken in } \\
\text { food (IN/EX-EMP) }\end{array}$ & - \\
\hline & ANC [26] & Head & $X X$ & Antidote & $\begin{array}{l}\text { The head of a fresh goatfish, } \\
\text { reduced to ashes, serves against } \\
\text { all poisons, especially against } \\
\text { those of mushrooms (IN-EMP) }\end{array}$ & 一 \\
\hline & MDR [35] & $\begin{array}{l}\text { Whole } \\
\text { animal }\end{array}$ & V & Alcoholism & $\begin{array}{l}\text { Those who drink wine in which a } \\
\text { goatfish was drowned, will be } \\
\text { averse to wine (IN-EMP) }\end{array}$ & - \\
\hline & MDR [36] & $\begin{array}{l}\text { Whole } \\
\text { animal }\end{array}$ & V & Alcoholism & $\begin{array}{l}\text { "The greatest way to make those } \\
\text { who get drunk reject wine is to } \\
\text { give them the liquid in which a } \\
\text { goatfish has been drowned" } \\
\text { (IN-EMP) }\end{array}$ & - \\
\hline & MDR [36] & $\begin{array}{l}\text { Whole } \\
\text { animal }\end{array}$ & V & Alcoholism & $\begin{array}{l}\text { "And causes tedium of wine to } \\
\text { drink that wine in which they } \\
\text { were drowned" (IN-EMP) }\end{array}$ & 一 \\
\hline & MDR [35] & $\begin{array}{l}\text { Whole } \\
\text { animal }\end{array}$ & $X \|$ & Carbuncle & $\begin{array}{l}\text { The ash of salted goatfish } \\
\text { (EX-EMP) }\end{array}$ & - \\
\hline & MDR [36] & $\begin{array}{l}\text { Whole } \\
\text { animal } \\
\text { (salting) }\end{array}$ & XII & Carbuncle & $\begin{array}{l}\text { Goatfish ash salt ... salt with } \\
\text { which they have been salted, } \\
\text { cures carbuncles (EX-EMP) }\end{array}$ & - \\
\hline & MDR [35] & Head & XIII & Sciatica & $\begin{array}{l}\text { The ash of several goatfish } \\
\text { heads, cures sciatica sufferers: } \\
\text { burn in a clay pot, and use as an } \\
\text { ointment mixed with honey } \\
\text { (EX-EMP) }\end{array}$ & - \\
\hline & MDR [35] & Meat & XIV & Menstruation problems & $\begin{array}{l}\text { Helps women when } \\
\text { menstruating (IN-EMP) }\end{array}$ & - \\
\hline & MDR [35] & Head & XIX & $\begin{array}{l}\text { Mushroom poisoning } \\
\text { (toxic effect) }\end{array}$ & $\begin{array}{l}\text { The fresh head ash is good } \\
\text { against any type of poison, and } \\
\text { particularly against fungi } \\
\text { (IN-EMP) }\end{array}$ & - \\
\hline & MDR [36] & Head & XIX & $\begin{array}{l}\text { Mushroom poisoning } \\
\text { (toxic effect) }\end{array}$ & $\begin{array}{l}\text { The ash from the head against all } \\
\text { poisons, and primarily against } \\
\text { fungi (IN-EMP) }\end{array}$ & - \\
\hline & MDR [35] & $\begin{array}{l}\text { Whole } \\
\text { animal, meat }\end{array}$ & $X X$ & Poisonous stings & $\begin{array}{l}\text { Pliny: goatfish is good to make } \\
\text { an ointment against stingrays, } \\
\text { both terrestrial and sea scorpions } \\
\text { (rockfish), dragons and falangia; } \\
\text { also good if eaten (IN/EX-EMP) }\end{array}$ & - \\
\hline & MDR [36] & $\begin{array}{l}\text { Whole } \\
\text { animal }\end{array}$ & $X X$ & Poisonous stings & $\begin{array}{l}\text { "In the book entitled Hortus } \\
\text { Sanitatis, Pliny says that: The } \\
\text { eating of mulo fish or rubbed in, } \\
\text { can aid against the damage } \\
\text { caused by stingrays, terrestrial } \\
\text { and marine scorpions, marine } \\
\text { dragons and falangios" } \\
\text { (IN/EX-EMP) }\end{array}$ & - \\
\hline & MDR [36] & $\begin{array}{l}\text { Whole } \\
\text { animal, meat }\end{array}$ & $X X$ & Antidote & $\begin{array}{l}\text { "Dioscorides says about these } \\
\text { fish: mulo being eaten very } \\
\text { frequently seems to obscure the } \\
\text { sight. Uncooked and cut into } \\
\text { pieces, and applied as a poultice, } \\
\text { it cures the bites of marine } \\
\text { dragons, and of scorpions and } \\
\text { spiders" (EX-EMP) }\end{array}$ & - \\
\hline Muraena helena & ANC [26] & Head & $X X$ & Bite & $\begin{array}{l}\text { Bites from moray are cured by } \\
\text { the ash of the head of the same } \\
\text { fish (EX-EMP) }\end{array}$ & - \\
\hline
\end{tabular}


Table 3 List of Spanish traditional remedies based on the use of fish (Continued)

\begin{tabular}{|c|c|c|c|c|c|c|}
\hline & MDR [35] & $\begin{array}{l}\text { Whole } \\
\text { animal }\end{array}$ & 1 & Leprosy & $\begin{array}{l}\text { Moray ash, with three óbolos of } \\
\text { honey (EX-EMP) }\end{array}$ & - \\
\hline & MDR [35] & $\begin{array}{l}\text { Whole } \\
\text { animal }\end{array}$ & $X I I$ & Lichen & $\begin{array}{l}\text { Moray ash, with three óbolos of } \\
\text { honey (EX-EMP) }\end{array}$ & - \\
\hline Ophisurus serpens & ANC [26] & $\begin{array}{l}\text { Whole } \\
\text { animal }\end{array}$ & XIV & Urinary incontinence & $\begin{array}{l}\text { Ophidion .... a little fish similar to } \\
\text { the conger, with iris root, and } \\
\text { the small fish removed that it } \\
\text { has eaten, burned, and the ashes } \\
\text { taken with water (IN-EMP) }\end{array}$ & - \\
\hline \multirow[t]{4}{*}{$\begin{array}{l}\text { Oreochromis } \\
\text { niloticus niloticus }\end{array}$} & ANC [26] & Meat & 1 & Abscesses & $\begin{array}{l}\text { The salt of salted coracinos } \\
\text { dissolves abscesses (EX-EMP) }\end{array}$ & - \\
\hline & ANC [26] & Bile & VII & Sharpen sight & $\begin{array}{l}\text { The bile of coracino also } \\
\text { sharpens of sight (IN-EMP) }\end{array}$ & - \\
\hline & ANC [26] & Meat & $X I I$ & Carbuncle & $\begin{array}{l}\text { An ointment of salted coracinos } \\
\text { reduces carbuncles (EX-EMP) }\end{array}$ & - \\
\hline & ANC [26] & Meat & $X X$ & Antidote & $\begin{array}{l}\text { Its meat ... with a topical } \\
\text { application is effective against } \\
\text { scorpions (EX-EMP) }\end{array}$ & - \\
\hline \multirow[t]{2}{*}{ Oxynotus centrina } & $\mathrm{CON}[76]$ & Liver & XIX & Heal burns & $\begin{array}{l}\text { Liver oil of the "peix porquet" } \\
\text { (EX-EMP) }\end{array}$ & Costa Brava (Gerona) \\
\hline & CON [76] & Liver & $X X$ & $\begin{array}{l}\text { To relieve pain in case of } \\
\text { poisonous fish bite (fish } \\
\text { spider, scorpion fish) }\end{array}$ & $\begin{array}{l}\text { Fishermen produce oil with fish } \\
\text { liver. Heat the oil and apply it } \\
\text { with a cloth (EX-EMP) }\end{array}$ & Costa Brava (Gerona) \\
\hline \multirow[t]{2}{*}{$\begin{array}{l}\text { Pagellus } \\
\text { erythrinus }\end{array}$} & ANC [26] & Meat & $X I$ & Laxative & $\begin{array}{l}\text { If eaten erythini act as a laxative } \\
\text { (IN-EMP) }\end{array}$ & - \\
\hline & ANC [26] & Meat & XIV & Increases libido & Eat (IN-EMP) & - \\
\hline \multirow[t]{4}{*}{ Perca fluviatilis } & ANC [26] & Vertebra & I & Quartan fevers (malaria) & $\begin{array}{l}\text { They say that carrying a perch } \\
\text { vertebra as a charm cures fever } \\
\text { (EX-MAG) }\end{array}$ & - \\
\hline & ANC [26] & Head & $\|$ & Carcinomas & $\begin{array}{l}\text { Heads in brine stop carcinomas, } \\
\text { more effective when the ashes } \\
\text { are mixed with salt and Satureja } \\
\text { and made into a paste with oil } \\
\text { (EX-EMP) }\end{array}$ & - \\
\hline & ANC [26] & Head & $X V$ & $\begin{array}{l}\text { Problems uterus, expulsion } \\
\text { of afterbirth }\end{array}$ & $\begin{array}{l}\text { The ash of perch heads with salt, } \\
\text { savory and oil cures the matrix, } \\
\text { and in fumigation expels the } \\
\text { afterbirth (EX-EMP) }\end{array}$ & - \\
\hline & MDR [38] & Otoliths & XIV & Renal colic (kidney stones) & $\begin{array}{l}\text { Make a fine powder, and grind } \\
\text { down crab eyes, the stones of } \\
\text { Perches Fish, and Merlancio: Take } \\
\text { the blood of Macho, Millet and } \\
\text { mealybugs, and add and store } \\
\text { for use. They are appropriate for } \\
\text { kidney stones, for sands, for } \\
\text { nephritic colic, and to excite the } \\
\text { urine. Its dosage is half a scruple } \\
\text { to a dragma (IN-EMP) }\end{array}$ & - \\
\hline $\begin{array}{l}\text { Raja clavata; } \\
\text { R. microocellata; } \\
\text { R. miraletus; } \\
\text { Leucoraja naevus }\end{array}$ & ANC [26] & Liver & $X I I$ & Pruritus, eczema & $\begin{array}{l}\text { The liver of ray cooked in oil very } \\
\text { effectively calms them (EX-EMP) }\end{array}$ & - \\
\hline Remora remora & ANC [26] & $\begin{array}{l}\text { Whole } \\
\text { animal }\end{array}$ & XIV & Inhibit sex drive & $\begin{array}{l}\text { Applied to the genitals inhibits } \\
\text { the loving impulse (EX-EMP) }\end{array}$ & - \\
\hline
\end{tabular}


Table 3 List of Spanish traditional remedies based on the use of fish (Continued)

\begin{tabular}{|c|c|c|c|c|c|c|}
\hline & ANC [26] & $\begin{array}{l}\text { Whole } \\
\text { animal }\end{array}$ & $X V$ & Nesting, early delivery & $\begin{array}{l}\text { Hung around the neck, they } \\
\text { delay pregnancies with a } \\
\text { premature tendency, and others, } \\
\text { if kept in salt and used as an } \\
\text { amulet, precipitates labour, and } \\
\text { therefore are called by a different } \\
\text { name, odynolites (EX-MAG) }\end{array}$ & - \\
\hline Salmo trutta & CON [49] & Tail & V & $\begin{array}{l}\text { Encourage early and } \\
\text { proper development of } \\
\text { language }\end{array}$ & $\begin{array}{l}\text { For the correct development of } \\
\text { language introduce into the } \\
\text { infant's mouth a trout tail } \\
\text { (IN-EMP) }\end{array}$ & $\begin{array}{l}\text { Sierra de Francia } \\
\text { (Salamanca) }\end{array}$ \\
\hline Sarda sarda & ANC [26] & & $X X$ & Antidote & $\begin{array}{l}\text { Against prester (viper) bite } \\
(\mathrm{IN}-\mathrm{EMP})\end{array}$ & - \\
\hline \multirow[t]{9}{*}{$\begin{array}{l}\text { Sardina } \\
\text { pilchardus }\end{array}$} & CON [57] & $\begin{array}{l}\text { Heads, } \\
\text { innards }\end{array}$ & $X \|$ & Sore feet and blisters & $\begin{array}{l}\text { Rub sore and blistered feet with } \\
\text { the intestines and heads of salty } \\
\text { sardines (EX-EMP) }\end{array}$ & $\begin{array}{l}\text { Sierra de Segura } \\
\text { (Albacete) }\end{array}$ \\
\hline & $\operatorname{CON}[42]$ & $\begin{array}{l}\text { Whole } \\
\text { animal }\end{array}$ & $\mathrm{XVl}$ & Forecast sex & $\begin{array}{l}\text { Put a sardine to the fire, in the } \\
\text { presence of the pregnant } \\
\text { woman. Failure to release the } \\
\text { scales, will mean a male, and if } \\
\text { the scale jumps then a female. In } \\
\text { Huesca the reverse is said } \\
\text { (EX-MAG) }\end{array}$ & Burgos, Huesca \\
\hline & CON [43] & Bone & $X V I$ & $\begin{array}{l}\text { For determining the sex } \\
\text { of an unborn baby }\end{array}$ & $\begin{array}{l}\text { Another type of superstitious } \\
\text { practice ... put on hot coals the } \\
\text { bone of a sardine, if it jumps or } \\
\text { flips it indicates the birth of a } \\
\text { boy (EX-MAG) }\end{array}$ & Basque Country \\
\hline & $\operatorname{CON}[51]$ & Bone & $\mathrm{XVl}$ & $\begin{array}{l}\text { For determining the sex } \\
\text { of an unborn baby }\end{array}$ & $\begin{array}{l}\text { Throwing a sardine bone onto } \\
\text { the fire to see if it jumps or flips } \\
\text { (EX-MAG) }\end{array}$ & Basque Country \\
\hline & CON [46] & $\begin{array}{l}\text { Whole } \\
\text { animal }\end{array}$ & $X V I I I$ & Bloating & $\begin{array}{l}\text { A cure based on the application } \\
\text { on the stomach of a poultice } \\
\text { made by kneading sardines in a } \\
\text { mortar with chopped celery, } \\
\text { adding barley flour and } \\
\text { sprinkling it with vinegar } \\
\text { (EX-EMP) }\end{array}$ & Villena (Alicante) \\
\hline & $\operatorname{CON}[46]$ & $\begin{array}{l}\text { Whole } \\
\text { animal }\end{array}$ & $X V I I I$ & Fever (unspecified) & $\begin{array}{l}\text { Apply to sole of the foot a salty } \\
\text { sardine half open, and then } \\
\text { bandaging (EX-MAG) }\end{array}$ & $\begin{array}{l}\text { Benilloba (Alicante); } \\
\text { Villores, Castillo de } \\
\text { Villamalefa (Castellón) }\end{array}$ \\
\hline & CON [63] & Head & XIX & Chilblains & $\begin{array}{l}\text { When were stale, sardine heads } \\
\text { were baked and the resulting } \\
\text { water was used to wash } \\
\text { chilblains (EX-EMP) }\end{array}$ & $\begin{array}{l}\text { Pandón de Lada - } \\
\text { Langreo- (Asturias) }\end{array}$ \\
\hline & CON [70] & Head & XIX & Chilblains & $\begin{array}{l}\text { Giving rubs with the head of a } \\
\text { sardine (EX-EMP) }\end{array}$ & La Aparecida (Alicante) \\
\hline & $\operatorname{CON}[46]$ & Innards & XIX & Chapped hands & $\begin{array}{l}\text { Cracks are rubbed with innards } \\
\text { of salted sardines (EX-EMP) }\end{array}$ & $\begin{array}{l}\text { Comarca de Los } \\
\text { Serranos (Valencia) }\end{array}$ \\
\hline Sciaena umbra & ANC [26] & $\begin{array}{l}\text { Intestines, } \\
\text { scales }\end{array}$ & XII & Abscesses & It dissolves them (EX-EMP) & - \\
\hline $\begin{array}{l}\text { Scophthalmus } \\
\text { maximus }\end{array}$ & ANC [26] & $\begin{array}{l}\text { Whole } \\
\text { animal }\end{array}$ & III & Diseases of spleen & $\begin{array}{l}\text { It is good to apply them, then } \\
\text { throw into the sea (EX-MAG) }\end{array}$ & - \\
\hline
\end{tabular}


Table 3 List of Spanish traditional remedies based on the use of fish (Continued)

\begin{tabular}{|c|c|c|c|c|c|c|}
\hline \multirow[t]{3}{*}{ Scorpaena porcus } & ANC [26] & Bile & 1 & Warts & Removes warts (EX-EMP) & - \\
\hline & ANC [26] & Bile & VII & $\begin{array}{l}\text { Incipient cataracts, } \\
\text { eye white spots }\end{array}$ & $\begin{array}{l}\text { Bile with rancid oil or Attic } \\
\text { honey. Rub on eyes three times } \\
\text { leaving several days in between } \\
\text { applications (IN-EMP) }\end{array}$ & - \\
\hline & MDR [36] & Bile & VII & $\begin{array}{l}\text { Cataracts, clouds and } \\
\text { vision problems }\end{array}$ & $\begin{array}{l}\text { Talking about this fish } \\
\text { Dioscorides, says: The bile of } \\
\text { marine scorpion, is helpful } \\
\text { against cataracts, against clouds, } \\
\text { and other weaknesses of sight } \\
\text { (IN-EMP) }\end{array}$ & - \\
\hline Scorpaena scrofa & ANC [27] & Bile & VII & Diseases of the eye & $\begin{array}{l}\text { The bile of red scorpionfish is } \\
\text { good for cataracts, walleye, } \\
\text { amblyopia (IN-EMP) }\end{array}$ & - \\
\hline \multirow{3}{*}{$\begin{array}{l}\text { Scyliorhinus } \\
\text { canicula }\end{array}$} & ANC [26] & Tooth & V & Sudden terrors & As an amulet (EX/MAG) & - \\
\hline & ANC [26] & Encephalon & $X I$ & Toothaches & $\begin{array}{l}\text { It sooths by scarifying the gums } \\
\text { (IN-EMP) }\end{array}$ & - \\
\hline & CON [62] & Skin & V & $\begin{array}{l}\text { Behaviour modification in } \\
\text { children who cleaned the } \\
\text { snot with the forearm }\end{array}$ & $\begin{array}{l}\ldots \text { To these children a piece of } \\
\text { fish skin was placed in the } \\
\text { sleeve, thus making them } \\
\text { abandon this bad habit (EX-EMP) }\end{array}$ & Basque Country \\
\hline \multirow[t]{13}{*}{ Silurus glanis } & ANC [27] & $\begin{array}{l}\text { Whole } \\
\text { animal }\end{array}$ & 1 & Dysentery & $\begin{array}{l}\text { Its brine, in sitting baths, is good } \\
\text { to those who begin to suffer } \\
\text { from dysentery, because it } \\
\text { attracts out flows and as enema } \\
\text { (IN/EX-EMP) }\end{array}$ & - \\
\hline & ANC [26] & Head & 1 & Erysipelas & $\begin{array}{l}\text { Salted wels catfish head ash } \\
\text { dissolved in vinegar (IN-EMP) }\end{array}$ & - \\
\hline & ANC [26] & Liver & 1 & Warts & Used topically (EX-EMP) & - \\
\hline & ANC [26] & Head & VII & Serpiginous ulcers & $\begin{array}{l}\text { The ash of the head of catfish } \\
\text { stops serpiginous ulcers, and } \\
\text { their excretions (EX-EMP) }\end{array}$ & - \\
\hline & ANC [26] & Meat & $x$ & Improves voice & Fresh or salted (IN-EMP) & - \\
\hline & ANC [27] & Meat & $x$ & Tracheitis, voice & $\begin{array}{l}\text { Salted wels catfish ... is not } \\
\text { nutritious but it purifies the } \\
\text { trachea and tempers the voice } \\
\text { (IN-EMP) }\end{array}$ & - \\
\hline & ANC [27] & Meat & $X I$ & Belly troubles & $\begin{array}{l}\text { Fresh wels catfish, eaten, is } \\
\text { nutritious and beneficial for the } \\
\text { stomach (IN-EMP) }\end{array}$ & - \\
\hline & ANC [26] & Meat & $X I$ & Laxative & $\begin{array}{l}\text { Wels catfish in its juices releases } \\
\text { the belly (IN-EMP) }\end{array}$ & - \\
\hline & ANC [26] & $\begin{array}{l}\text { Whole } \\
\text { animal }\end{array}$ & $X \|$ & Pyoderma gangrenosum & $\begin{array}{l}\text { Phagedenic ulcer is cured with } \\
\text { rancid catfish crushed with } \\
\text { rejalgar (EX-EMP) }\end{array}$ & - \\
\hline & ANC [26] & Meat & XIII & Sciatica & $\begin{array}{l}\text { The brine of wels catfish, } \\
\text { administered as enema, after } \\
\text { evacuation (IN-EMP) }\end{array}$ & - \\
\hline & ANC [27] & $\begin{array}{l}\text { Whole } \\
\text { animal }\end{array}$ & XIII & Sciatica & $\begin{array}{l}\text { And its brine, in a sitting bath, } \\
\ldots . \text {, cures those affected by } \\
\text { sciatica (EX-EMP) }\end{array}$ & - \\
\hline & ANC [26] & - & $X V$ & Facilitate delivery & $\begin{array}{l}\text { It is also said that fumigation of } \\
\text { catfish, especially if it is African } \\
\text { make simpler deliveries (EX-EMP) }\end{array}$ & - \\
\hline & ANC [26] & Meat & XIX & Foreign bodies in the skin & $\begin{array}{l}\text { Splinters lodged in the body are } \\
\text { extracted with ... the use of river } \\
\text { catfish meat (EX-EMP) }\end{array}$ & - \\
\hline
\end{tabular}


Table 3 List of Spanish traditional remedies based on the use of fish (Continued)

\begin{tabular}{|c|c|c|c|c|c|c|}
\hline & ANC [27] & Meat & XIX & Expel thorns & $\begin{array}{l}\text { Salted meat, applied as a } \\
\text { poultice, expels splinters } \\
\text { (EX-EMP) }\end{array}$ & - \\
\hline & MED [34] & Meat & IV & Metabolism & $\begin{array}{l}\text { When you eat the flesh of this } \\
\text { fish, if eaten fresh, it nourishes } \\
\text { and slows nature. If salted less so } \\
\text { (IN-EMP) }\end{array}$ & 一 \\
\hline & MED [34] & - & $x$ & Apnoea, throat & $\begin{array}{l}\text { It's useful for shallow breathing } \\
\text { and useful for a good voice (?) }\end{array}$ & 一 \\
\hline & MED [34] & $\begin{array}{l}\text { Whole } \\
\text { animal }\end{array}$ & $X I$ & Intestinal ulcers & $\begin{array}{l}\text { The salting water is good for } \\
\text { intestinal ulcers if you make a } \\
\text { enema with it, also if the person } \\
\text { sits on top (IN-EMP) }\end{array}$ & 一 \\
\hline & MED [34] & Bile & $X I I I$ & Sciatica & $\begin{array}{l}\text { The bile, mixed with musk, is } \\
\text { good for sciatica (EX-EMP) }\end{array}$ & 一 \\
\hline & MDR [36] & Meat & 1 & Dysentery & $\begin{array}{l}\text { "If you bathe in its brine, it is } \\
\text { helpful at the beginning of the } \\
\text { dysentery, because it attracts to } \\
\text { the surface the humours that are } \\
\text { in the belly" (EX-MAG) }\end{array}$ & - \\
\hline & MDR [36] & Meat & XIII & Sciatica & $\begin{array}{l}\text { "It heals sciatica, taken after } \\
\text { fasting" (IN-EMP) }\end{array}$ & - \\
\hline & MDR [36] & Meat & $X X$ & Chips kneeling & $\begin{array}{l}\text { "It removes swollen splinters } \\
\text { from any part of the body" } \\
(\text { EX-EMP) }\end{array}$ & - \\
\hline \multirow[t]{2}{*}{ Solea solea } & ANC [26] & $\begin{array}{l}\text { Whole } \\
\text { animal }\end{array}$ & $\|$ & $\begin{array}{l}\text { Splenic tumour } \\
\text { (malignant neoplasm } \\
\text { of spleen) }\end{array}$ & $\begin{array}{l}\text { It is good to apply, then throw it } \\
\text { into the sea (EX-MAG) }\end{array}$ & - \\
\hline & MDR [35] & Meat & IV & Sick diet & $\begin{array}{l}\text { According to doctors, it is a very } \\
\text { light food for the sick, it is less } \\
\text { phlegmatic than others ... } \\
\text { (IN-EMP) }\end{array}$ & \\
\hline $\begin{array}{l}\text { Sparisoma } \\
\text { cretense }\end{array}$ & ANC [28] & Bile & $X V I I I$ & Jaundice & $\begin{array}{l}\text { If a sick man you give him escaro } \\
\text { bile to eat then he will heal, as } \\
\text { taught by experienced fishermen } \\
\text { (IN-EMP) }\end{array}$ & - \\
\hline Sparus aurata & ANC [26] & Meat & $X X$ & Antidote & $\begin{array}{l}\text { Where there is poisonous honey } \\
\text { produced, the remedy is to eat } \\
\text { gilt-head bream (IN-EMP) }\end{array}$ & - \\
\hline
\end{tabular}


Table 3 List of Spanish traditional remedies based on the use of fish (Continued)

\begin{tabular}{|c|c|c|c|c|c|c|}
\hline & ANC [26] & Head & $\mathrm{VII}$ & Serpiginous ulcers & $\begin{array}{l}\text { The ash of mena head stops } \\
\text { serpiginous ulcers, and their } \\
\text { excretions (EX-EMP) }\end{array}$ & - \\
\hline & ANC [26] & Head & $x$ & Tonsils & $\begin{array}{l}\text { Ash of salted heads applied with } \\
\text { honey (EX-EMP) }\end{array}$ & - \\
\hline & ANC [26] & Head & $X \mid$ & Anal fissures & Ashes of the head (EX-EMP) & - \\
\hline & ANC [27] & Head & $X I$ & Anal fissures & $\begin{array}{l}\text { The burnt head, pulverized, } \\
\text { removes anal cracks (EX-EMP) }\end{array}$ & - \\
\hline & ANC [27] & Guts & $X I$ & Mouth sores & $\begin{array}{l}\text { The "garo" (garum) used as a } \\
\text { mouthwash heals festering sores } \\
\text { in the mouth (IN-EMP) }\end{array}$ & - \\
\hline & ANC [26] & $\begin{array}{l}\text { Whole } \\
\text { animal, head }\end{array}$ & $X I$ & Mouth ulcers & $\begin{array}{l}\text { The brine from the mena and } \\
\text { ash of the head heal mouth } \\
\text { ulcers (IN-EMP) }\end{array}$ & - \\
\hline & ANC [26] & $\begin{array}{l}\text { Whole } \\
\text { animal }\end{array}$ & $X I$ & Laxative & $\begin{array}{l}\text { Salted mena spread on the naval } \\
\text { with bull bile causes the release } \\
\text { of the belly (EX-EMP) }\end{array}$ & - \\
\hline & ANC [26] & Head & $X \|$ & Nail harshness & $\begin{array}{l}\text { The ash of mena heads soften } \\
\text { the rough edges of nails } \\
\text { (EX-EMP) }\end{array}$ & - \\
\hline & ANC [26] & Head & $X V$ & $\begin{array}{l}\text { Problems uterus, } \\
\text { expulsion of afterbirth }\end{array}$ & $\begin{array}{l}\text { The ash of the heads of mena } \\
\text { heads with salt, savory, and oil } \\
\text { cure the matrix, and as a } \\
\text { fumigation expel the afterbirth } \\
\text { (IN-EMP) }\end{array}$ & - \\
\hline & MDR [36] & $\begin{array}{l}\text { Whole } \\
\text { animal }\end{array}$ & $X I$ & Mouth sores & $\begin{array}{l}\text { "Its brine dries up mouth sores } \\
\text { full of corruption, if used as } \\
\text { mouthwash" (IN-EMP) }\end{array}$ & - \\
\hline & MDR [36] & Head & $X I$ & Anal fissures & $\begin{array}{l}\text { "About this fish Dioscorides says: } \\
\text { The ash from head of salted } \\
\text { Menas, heals the anal cracks" } \\
\text { (EX-EMP) }\end{array}$ & - \\
\hline Spicara smaris & ANC [26] & $\begin{array}{l}\text { Whole } \\
\text { animal }\end{array}$ & 1 & Warts & $\begin{array}{l}\text { Crushed and applied on warts } \\
\text { (EX-EMP) }\end{array}$ & - \\
\hline & ANC [27] & Head & 1 & Scab and plantar warts & $\begin{array}{l}\text { The burnt head of salted caramel } \\
\text { reduces scab and warts ... } \\
\text { (EX-EMP) }\end{array}$ & - \\
\hline & ANC [27] & Head & $X I X$ & $\begin{array}{l}\text { Healing wounds and } \\
\text { ulcers }\end{array}$ & $\begin{array}{l}\text { The salted burnt head of the } \\
\text { caramel reduces sores and stops } \\
\text { fleshy excretion and infection } \\
\text { (EX-EMP) }\end{array}$ & - \\
\hline & ANC [27] & Head & $X X$ & Bites and stings & $\begin{array}{l}\text { The salted burnt head of the } \\
\text { caramel... goes well against } \\
\text { scorpion stings and dog bites } \\
\text { (EX-EMP) }\end{array}$ & - \\
\hline & ANC [26] & Meat & $X V$ & Increase milk production & $\begin{array}{l}\text { Taken with barley or cooked with } \\
\text { fennel (IN-EMP) }\end{array}$ & - \\
\hline & MDR [36] & Head & 1 & Scab and plantar warts & $\begin{array}{l}\text { Removes hardened scab and } \\
\text { warts (?) }\end{array}$ & - \\
\hline & MDR [36] & Head & $X \|$ & Ulcers & $\begin{array}{l}\text { "The Smarido head, salted and } \\
\text { burnt, represses the growth on } \\
\text { the wounds and reduces those } \\
\text { about to break out" (EX-EMP) }\end{array}$ & - \\
\hline & MDR [36] & Meat & $X X$ & Dog bites & $\begin{array}{l}\text { "Its salted meat, like almost all } \\
\text { brine, is helpful against dog } \\
\text { bites" (EX-EMP) }\end{array}$ & - \\
\hline & MDR [36] & Meat & $x X$ & Scorpion stings & $\begin{array}{l}\text { "Its salted meat, like almost all } \\
\text { brine, is helpful against scorpion } \\
\text { stings" (EX-EMP) }\end{array}$ & - \\
\hline
\end{tabular}


Table 3 List of Spanish traditional remedies based on the use of fish (Continued)

\begin{tabular}{|c|c|c|c|c|c|c|}
\hline Squalus acanthias & MED [32] & $\begin{array}{l}\text { Whole } \\
\text { animal }\end{array}$ & $\mathrm{Vl}$ & Convulsions & $\begin{array}{l}\text { Crush, cook and make a poultice } \\
\text { (EX-EMP) }\end{array}$ & - \\
\hline \multirow[t]{3}{*}{$\begin{array}{l}\text { Squatina oculata; } \\
\text { Squatina squatina }\end{array}$} & ANC [26] & Skin & 1 & Abscesses & $\begin{array}{l}\text { Applying the burnt skin } \\
\text { (EX-EMP) }\end{array}$ & - \\
\hline & ANC [26] & $\begin{array}{l}\text { Whole } \\
\text { animal }\end{array}$ & XIV & Stop breast growth & $\begin{array}{l}\text { The application of angelshark } \\
\text { impedes the growth of the } \\
\text { breasts (EX-MAG) }\end{array}$ & - \\
\hline & CON [66] & Roe & $x$ & Asthma & $\begin{array}{l}\text { "Angelote" (Squatina squatina L.) } \\
\ldots \text {. its roe (eggs) collected on } \\
\text { Good Friday cure asthma } \\
\text { (IN-MAG) }\end{array}$ & $\begin{array}{l}\text { Gran Canaria (Canary } \\
\text { Islands) }\end{array}$ \\
\hline \multirow[t]{15}{*}{ Thunnus thynnus } & ANC [26] & Head & I & Abscesses & Applying head ash (EX-EMP) & - \\
\hline & ANC [26] & Head & I & Genital warts & $\begin{array}{l}\text { The head of salted pelamys } \\
\text { [one year old tuna] with honey } \\
\text { (EX-EMP) }\end{array}$ & - \\
\hline & ANC [26] & Meat & $X I$ & Toothaches & $\begin{array}{l}\text { Rancid tuna, washed in a bowl } \\
\text { and crushed is effective (IN-EMP) }\end{array}$ & - \\
\hline & ANC [26] & Head & $X I$ & Anal fissures & $\begin{array}{l}\text { The head of salted pelamys [one } \\
\text { year old tuna] with honey (EX- } \\
\text { EMP) }\end{array}$ & - \\
\hline & ANC [26] & Meat & $X I I$ & $\begin{array}{l}\text { Malignant ulcers, corrosive } \\
\text { and rotten }\end{array}$ & $\begin{array}{l}\text { With pieces of stale tuna (EX- } \\
\text { EMP) }\end{array}$ & - \\
\hline & ANC [28] & Blood & $X I I$ & Depilatory & $\begin{array}{l}\text { If a young man desires to be } \\
\text { without beard for a very long } \\
\text { time, if he smears that part with } \\
\text { tuna blood he will remain } \\
\text { hairless (EX-EMP) }\end{array}$ & - \\
\hline & ANC [27] & $\begin{array}{l}\text { Whole } \\
\text { animal }\end{array}$ & $X X$ & Dog bite & Apply as a poultice (EX-EMP) & - \\
\hline & ANC [27] & Meat & $x X$ & Viper bite & $\begin{array}{l}\text { The so-called "salting raw" (ömo- } \\
\text { tárikhos) is preserved salted tuna } \\
\text { meat. If taken it assists those bit- } \\
\text { ten by the snake called "that } \\
\text { which swells" (prëstêr), it is neces- } \\
\text { sary to add the maximum } \\
\text { amount of wine and to drink } \\
\text { heavily to force them to vomit } \\
\text { (IN-EMP) }\end{array}$ & - \\
\hline & ANC [26] & Meat & $X X$ & Antidote & Against the sea dragon (IN-EMP) & - \\
\hline & MDR [36] & Meat & $X I$ & Indigestion & $\begin{array}{l}\text { "It's also useful to provoke the } \\
\text { vomiting of meals that bother } \\
\text { the stomach" (IN-EMP) }\end{array}$ & - \\
\hline & MDR [35] & Liver & $X \|$ & Cosmetics & $\begin{array}{l}\text { Its liver, chopped and mixed with } \\
\text { cedar oil, preserved in a lead } \\
\text { chest, outline the eyelids (EX- } \\
\text { EMP) }\end{array}$ & - \\
\hline & MDR [35] & $\begin{array}{l}\text { Blood, bile, } \\
\text { liver }\end{array}$ & $X \|$ & Depilatory & $\begin{array}{l}\text { From the blood, bile and liver of } \\
\text { tuna, fresh or preserved, a cream } \\
\text { is made (EX-EMP) }\end{array}$ & - \\
\hline & MDR [35] & $\begin{array}{l}\text { Whole } \\
\text { animal }\end{array}$ & $x X$ & Dog bites & Applied in poultices (EX-EMP) & - \\
\hline & MDR [36] & Meat & $X X$ & Dog bites & $\begin{array}{l}\text { Useful applied against dog bites } \\
\text { (EX-EMP) }\end{array}$ & - \\
\hline & MDR [35] & Meat & $x X$ & Snake bites (antidote) & $\begin{array}{l}\text { Dioscorides: If you eat a lot of } \\
\text { salted tuna, harm from snakebite } \\
\text { is reduced (IN-EMP) }\end{array}$ & - \\
\hline
\end{tabular}


Table 3 List of Spanish traditional remedies based on the use of fish (Continued)

\begin{tabular}{|c|c|c|c|c|c|c|}
\hline & MDR [36] & Meat & $X X$ & Viper bites & $\begin{array}{l}\text { "Salted tuna, which is called in } \\
\text { the Greek language Omotarichos, } \\
\text { if eaten in large quantities, cures } \\
\text { the bites from the viper called } \\
\text { Prester. But you should give it } \\
\text { with a large amount of wine, } \\
\text { and force them to vomit" } \\
\text { (IN-EMP) }\end{array}$ & - \\
\hline \multirow{11}{*}{$\begin{array}{l}\text { Torpedo } \\
\text { marmorata; } \\
\text { Torpedo torpedo }\end{array}$} & ANC [26] & $\begin{array}{l}\text { Whole } \\
\text { animal }\end{array}$ & III & Spleen diseases & $\begin{array}{l}\text { It is good to apply, then throw it } \\
\text { into the sea (EX-MAG) }\end{array}$ & - \\
\hline & ANC [26] & $\begin{array}{l}\text { Whole } \\
\text { animal }\end{array}$ & $X I$ & Laxative & $\begin{array}{l}\text { Marbled electric ray in its juices } \\
\text { releases the belly (IN-EMP) }\end{array}$ & - \\
\hline & ANC [27] & $\begin{array}{l}\text { Whole } \\
\text { animal }\end{array}$ & $X I$ & Rectal prolapse & $\begin{array}{l}\text { Applied in the anus it reduces } \\
\text { anal prolapse (EX-EMP) }\end{array}$ & - \\
\hline & ANC [28] & Meat & $X I I$ & Depilatory & $\begin{array}{l}\text { If its meat is subjected to a } \\
\text { process of putrefaction in } \\
\text { vinegar and smeared onto the } \\
\text { chin, the effect is said to be the } \\
\text { disappearance of hair (EX-EMP) }\end{array}$ & - \\
\hline & ANC [26] & Bile & XIV & Inhibits sex drive & $\begin{array}{l}\text { Applied to the genitals it inhibits } \\
\text { the sexual impulse (EX-EMP) }\end{array}$ & - \\
\hline & ANC [26] & $\begin{array}{l}\text { Whole } \\
\text { animal }\end{array}$ & $X V$ & Facilitate delivery & $\begin{array}{l}\text { If you capture a marbled electric } \\
\text { ray when the moon is in the sign } \\
\text { of Libra and keep it for three } \\
\text { days outdoors, then deliveries } \\
\text { are made easy, as often as it is } \\
\text { presented to a woman in labour } \\
\text { (EX-MAG) }\end{array}$ & - \\
\hline & ANC [27] & $\begin{array}{l}\text { Whole } \\
\text { animal }\end{array}$ & $X V I I I$ & Headache & $\begin{array}{l}\text { Applied in cases of chronic } \\
\text { headaches, it alleviates the } \\
\text { severity of the pain (EX-EMP) }\end{array}$ & - \\
\hline & MDR [35] & $\begin{array}{l}\text { Whole } \\
\text { animal }\end{array}$ & III & Spleen diseases & $\begin{array}{l}\text { Used as a poultice, it cures the } \\
\text { spleen (EX-EMP) }\end{array}$ & - \\
\hline & MDR [35] & Meat & $X I$ & Digestive & $\begin{array}{l}\text { Pliny, book 32: Taken as food, the } \\
\text { marbled electric ray softens the } \\
\text { belly (IN-EMP) }\end{array}$ & - \\
\hline & MDR [35] & $\begin{array}{l}\text { Whole } \\
\text { animal }\end{array}$ & $X I$ & Hernia & $\begin{array}{l}\text { Placed on top it inhibits the } \\
\text { illness that causes the fall of the } \\
\text { intestine (EX-EMP) }\end{array}$ & - \\
\hline & MDR [36] & Meat & $X V I I I$ & Headache & $\begin{array}{l}\text { "... because as Galen says, it has } \\
\text { the virtue of removing headache, } \\
\text { placed on it, and also so says } \\
\text { Dioscorides, that it relaxes the } \\
\text { head" (EX-EMP) }\end{array}$ & - \\
\hline \multirow[t]{4}{*}{ Trachinus draco } & ANC [26] & Bones & $X I$ & Toothache & $\begin{array}{l}\text { Sea dragon bones soothe the } \\
\text { gums (IN-EMP) }\end{array}$ & - \\
\hline & ANC [26] & Meat & $X X$ & Stings & $\begin{array}{l}\text { The sea dragon sting is cured by } \\
\text { directly applying its own meat } \\
\text { (EX-EMP) }\end{array}$ & - \\
\hline & ANC [26] & $\begin{array}{l}\text { Whole } \\
\text { animal, brain }\end{array}$ & $X X$ & Antidote & $\begin{array}{l}\text { Against the venom of the sting } \\
\text { of the sea dragon the application } \\
\text { of the fish itself is effective, or a } \\
\text { potion made from its own brain } \\
\text { (EX-EMP) }\end{array}$ & - \\
\hline & ANC [26] & Meat & $X X$ & Antidote & $\begin{array}{l}\text { The sting is cured by applying } \\
\text { the meat (directly) (EX-EMP) }\end{array}$ & - \\
\hline
\end{tabular}


Table 3 List of Spanish traditional remedies based on the use of fish (Continued)

\begin{tabular}{|c|c|c|c|c|c|c|}
\hline & ANC [27] & $\begin{array}{l}\text { Whole } \\
\text { animal }\end{array}$ & $X X$ & Antidote & $\begin{array}{l}\text {... opened up and applied over } \\
\text { the wound is a cure for its own } \\
\text { sting (EX-EMP) }\end{array}$ & - \\
\hline & MDR [36] & $\begin{array}{l}\text { Whole } \\
\text { animal }\end{array}$ & $X X$ & $\begin{array}{l}\text { Wound he did with his } \\
\text { own spine }\end{array}$ & $\begin{array}{l}\text { "Dioscorides says: the Marine } \\
\text { Dragon, opened and applied, } \\
\text { heals the wound caused by its } \\
\text { own sting" (EX-EMP) }\end{array}$ & - \\
\hline & MDR [35] & $\begin{array}{l}\text { Whole } \\
\text { animal }\end{array}$ & $X X$ & Antidote & $\begin{array}{l}\text { Pliny... Likewise, the sea dragon } \\
\text { itself is good if it placed as a } \\
\text { poultice against the venom of its } \\
\text { sting, which caused the wound./ } \\
\text { Avicenna... The same author in } \\
\text { the second book: As Galen says, } \\
\text { the sea dragon is sliced and } \\
\text { placed on their own bite as a } \\
\text { cure (EX-EMP) }\end{array}$ & - \\
\hline \multirow[t]{4}{*}{ Trachinus radiatus } & ANC [26] & $\begin{array}{l}\text { Whole } \\
\text { animal }\end{array}$ & I & Abscesses & $\begin{array}{l}\text { Cooked in wine, thereby making } \\
\text { poultices, the abscesses are } \\
\text { dissolved (EX-EMP) }\end{array}$ & - \\
\hline & ANC [26] & $\begin{array}{l}\text { Whole } \\
\text { animal }\end{array}$ & $X I$ & Liver pain & $\begin{array}{l}\text { Drowned in wine, then drank } \\
\text { (IN-EMP) }\end{array}$ & - \\
\hline & ANC [26] & Bile & $X \|$ & Scars & $\begin{array}{l}\text { Applied directly removes scars } \\
\text { (EX-EMP) }\end{array}$ & - \\
\hline & ANC [26] & Meat & $X X$ & Antidote & $\begin{array}{l}\text { The sting is cured by applying } \\
\text { the meat (EX-EMP) }\end{array}$ & - \\
\hline $\begin{array}{l}\text { Trachurus } \\
\text { trachurus }\end{array}$ & ANC [26] & Liver & I & Mumps & - & - \\
\hline \multirow[t]{3}{*}{ Trigla lyra } & ANC [27] & Meat & $X X$ & Bites, antidote & $\begin{array}{l}\text { The trigla, raw, split and applied } \\
\text { it cures the bites of sea spider, } \\
\text { sea scorpion and spiders } \\
\text { (EX-EMP) }\end{array}$ & - \\
\hline & MED [34] & $\begin{array}{l}\text { Skinned } \\
\text { animal }\end{array}$ & $X \|$ & Pustules & $\begin{array}{l}\text { The triga skinned and placed on } \\
\text { the pustules of the body, cures } \\
\text { and heals them (EX-EMP) }\end{array}$ & - \\
\hline & MED [34] & $\begin{array}{l}\text { Whole } \\
\text { animal }\end{array}$ & $X X$ & $\begin{array}{l}\text { Foreign bodies deep in } \\
\text { the body }\end{array}$ & $\begin{array}{l}\text { Crushed and smeared on a site } \\
\text { where there is an arrowhead or a } \\
\text { thorn stuck deep in the body, it } \\
\text { extracts them thanks to its } \\
\text { vigorous nature and amazing } \\
\text { properties (EX-EMP) }\end{array}$ & - \\
\hline $\begin{array}{l}\text { Trigloporus } \\
\text { lastoviza }\end{array}$ & MED [34] & $\begin{array}{l}\text { Whole } \\
\text { animal }\end{array}$ & $X X$ & $\begin{array}{l}\text { Contact with venomous } \\
\text { animals }\end{array}$ & $\begin{array}{l}\text { If cut up and placed on a } \\
\text { jellyfish, scorpion or spider sting, } \\
\text { it feels good (EX-EMP) }\end{array}$ & - \\
\hline $\begin{array}{l}\text { Uranoscopus } \\
\text { scaber }\end{array}$ & ANC [26] & Bile & VII & Eye wounds & $\begin{array}{l}\text { Heals scars and removes growths } \\
\text { from the eye. No other fish has } \\
\text { such an abundant bile (IN-EMP) }\end{array}$ & - \\
\hline
\end{tabular}

Historical periods: ANC = Ancient; MED = Medieval; MDR = "Modern" (15th-19th centuries); CON = "Contemporary" (20th century-at present). Route of administration: IN = internal use; $E X=$ external use. Type of remedy: $M A G=$ magical remedy, $E M P=$ empirical remedy.

This description is compatible with $C$. linearis, which has a size of $4.7 \mathrm{~cm}$ in the male and $3.9 \mathrm{~cm}$ in the female, it has a big mouth, its first dorsal fin has two conspicuous radios in the male and external muscle segments just as suggested the text. Its range includes the Atlantic (it goes as far as Gibraltar) and the Mediterranean. It is a benthic species commonly found on shells and on sandy bottoms. In Dioscorides, some authors associate the word "gobio" to the Gobio gobio species [27], which is a freshwater fish with a small mouth and which lives in sediment covered beds. Andrés de Laguna, commenting Dioscorides, states that:

"The gobio is a well known fish on all the shores of the Adriatic Sea, although it is also found in some lakes and rivers, the head of the gobio is in proportion to the body, very great: it is very tasty and easily digested, having very delicate meat and is a good nutrient, mainly those which are caught between some rocks" [90]. 
From the explanation in "Del Scorpion Marino" we get Scorpaena porcus:

"The Scorpion grows within the Pielago, and Scorpina in more swampy places. Scorpion is red in colour and Scorpina almost black. "He" is good gentle food and "she" not so. Scorpion has a flap on the back with twelve sharp spikes, and a very large spiked head: it has short, thick teeth and very small, thin almost invisible scales" [36].

The morphological character, a large head and a dorsal fin with 12 hard spines and 10 soft rays allows the identification of S. porcus. These characteristics of the species distinguished it from Trachinus radiatus also known in Spain as "escorpión" (scorpion) or "araña" (spider), which is of a dark colour on the back and has six hard poisonous rays in the first of the two dorsal fins. It should be noted that Pliny refers to both the dragon and the scorpion when he writes "which have stings in the gills facing the tail, and thus sting like a scorpion when you pick them up" [26]. In this case the "scorpion" would be T. radiatus, in addition to the characteristics described, presents poisonous opercula spines oriented toward the tail.

\section{Ethnomedical practices: useful species and remedy features}

Many species documented in this study as useful in the therapeutic are species currently marketed and consumed in Spain (Figure 1). The most historically important fish species, with use-reports in the 20th century and in one or more past periods, and whose usage has survived over time, are: Acipenser sturio, Anguilla anguilla, Engraulis encrasicolus, Halobatrachus didactylus, Hippocampus sp., Scyliorhinus canicula and Squatina sp. (see Table 2).

Cod (Gadus morhua) is the species for which we have found a large number of use-reports (24). Although some remedies are based on the use of its jawbones, fins or gills, the importance of this species lies in the frequent use of cod liver oil to treat nutritional problems and the intake of meat of dried and salted cod to stimulate the secretion of milk and prevent seasickness. At this point, it should be noted that the salt cod was for many decades the only fish stored and consumed by the rural communities of the central part of Spanish territory (Figure 2).

According to the results obtained from the statistical analysis performed to evaluate the features of the different remedies found, we can conclude that the route of administration of a remedy and the periodization (historical periods $v s$. contemporary times) are independent $\left(\chi^{2}=2.850\right.$, $\mathrm{df}=1, \mathrm{p}=0.091)$. By contrast, there does exist an association between the type of remedy and the periodization $\left(\chi^{2}=15.751, \mathrm{df}=1, \mathrm{p}<0.0001\right)$, they are not independent.
The number of fish-based empirical remedies is significantly larger as well as the number of magical remedies in the case of the historical periods (Figure 3). These differences are not due to random chance.

\section{Concerning therapeutic foundations and medicinal value}

Magic and superstition are poorly understood concepts in some contexts and situations. Many remedies can be labelled as superstitions or magic, but is all that is branded superstitious or magical really so? From an anthropological viewpoint magic can be defined as "a combination of beliefs and practices based on the conviction that the human being can intervene in natural determinism, albeit completing or modifying it, by means of the manipulation of certain powers, accessible through aptitudes, knowledge, or special techniques" and superstition as "a knowledge or belief considered erroneous and not accepted by whoever has the authority to distinguish between legitimate and illegitimate knowledge" [91,92].

Superstition in medicine has been evaluated by Luis Gil in his work Therapeia. La medicina popular en el mundo clásico [93] in which he interprets the curative procedures of the animal-based medicine throughout history, with some words from MacKinney [94].

"It cannot be denied that the later Greek writings in medicine contain remedies that are more primitive than those of Hippocrates' time. The same phenomenon, rise in superstitious prescriptions when a civilization ages, can be observed in other historical periods, especially in Ancient Egypt and Medieval Europe. However, this fact does not justify the conclusion that medical science gives way to superstition when a civilization ages. Thus, the writings of the later centuries contain an ever-increasing load of data, not only of science, but also of superstition, which includes that transmitted in previous eras. The Ebers Papyrus contains recipes from previous periods. The same is true of $D e$

Materia Medica, compiled by Dioscorides in the late period of the Greek civilisation" [93].

In zootherapy it can be affirmed that belief systems have been significant throughout history. Empedocles and Plato considered the importance of therapy not based on reason $[95,96]$.

The magical theme of medicine is observed in the remedies compiled, in such a way that some are based on "transferential therapy", where the illness or pain is redirected to the animal, as happens in the case of poisonous bites or stings. We can cite, for example, species that act as antidotes when applied directly to the skin, such as Sarda sarda, Thunnus thynnus, Mullus sp. (M. barbatus barbatus, M. surmuletus), Trachinus draco, T. radiatus, Scorpaena porcus or Dasyatis pastinaca (see Table 3). 

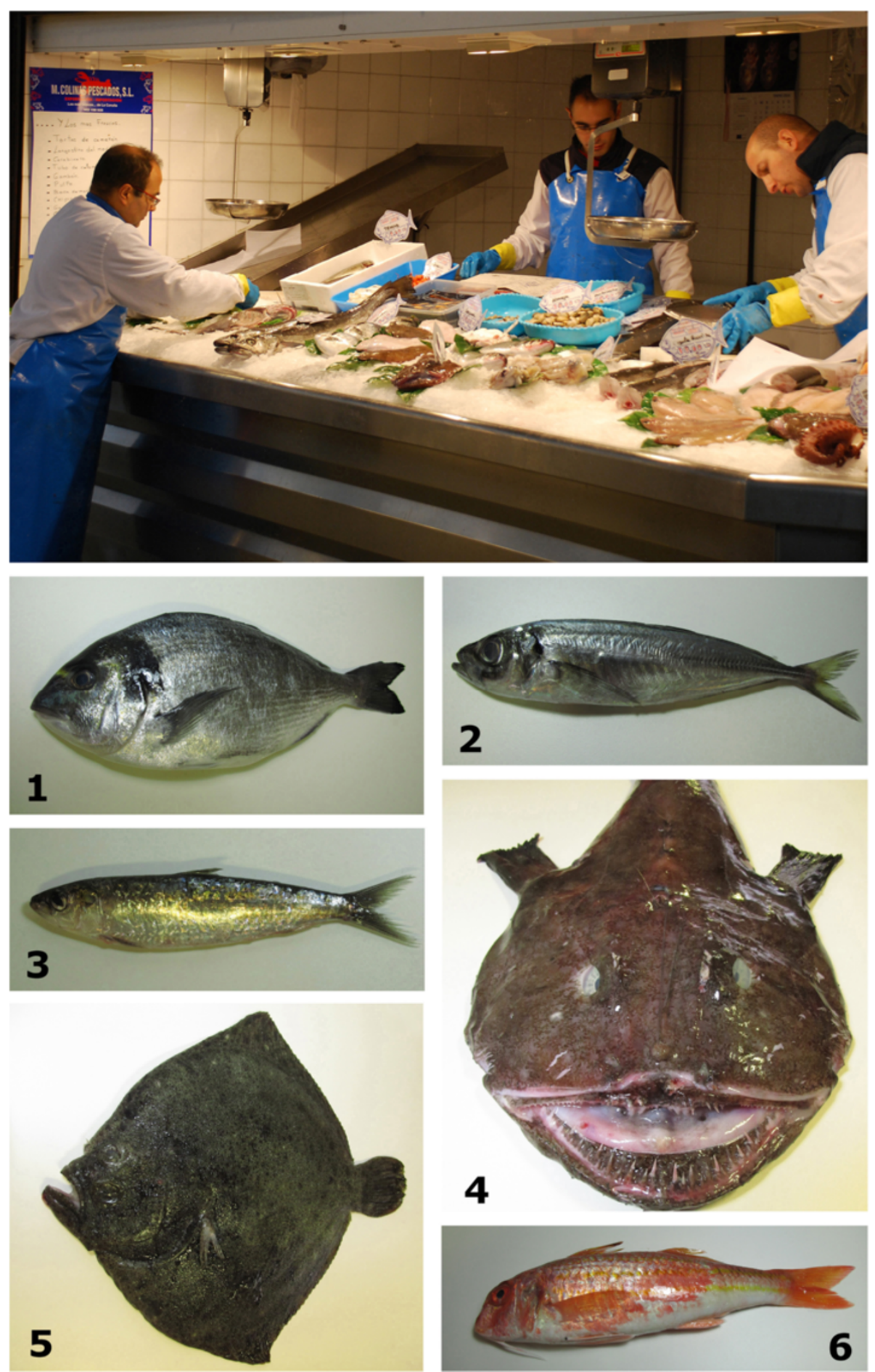

Figure 1 Examples of medicinal fishes traded in Spanish fish markets and consumed as food. (1) gilt-head bream, Sparus aurata; (2) Atlantic horse mackerel, Trachurus trachurus; (3) sardine or European pilchard, Sardina pilchardus; (4) angler, fishing-frog, frog-fish or sea-devil, Lophius piscatorius; (5) turbot, Scophthalmus maximus; (6) striped red mullet, Mullus surmuletus.

Astrology exercised an influence on ancient pharmacopoeia by relating therapeutic capacity to favourable astral constellations. In the Zodiac Man or homo signorum of Burriana (province of Castellón) we can observe that a link was established between the astrological signs and various parts of the body [97]. Thus, we find that by presenting a woman in labour with a "tembladera" (Torpedo marmorata, $T$. torpedo), caught when the moon is in 


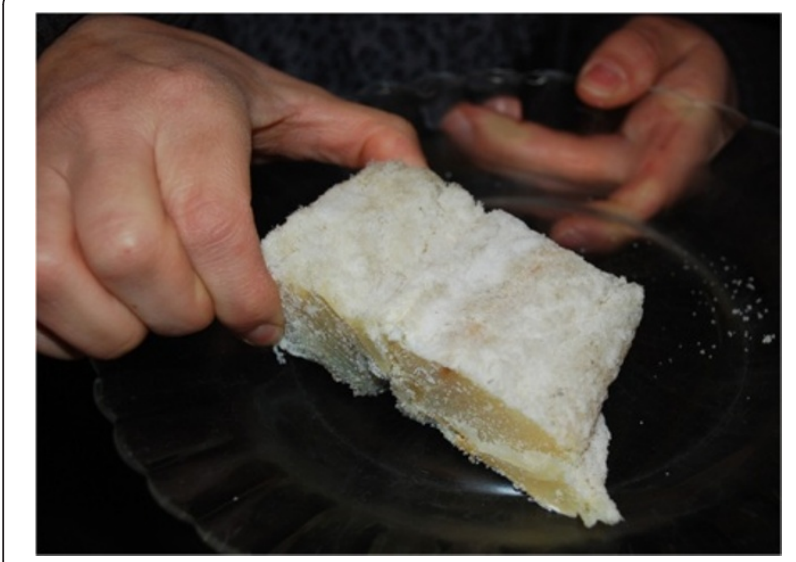

Figure 2 A bit of dried and salted cod. In Spain the "bacalao" is used in the culinary preparation of numerous and diverse traditional dishes. This product is consumed raw in salads, stewed or eaten fried.

Libra, the delivery will be made easier. The astrological systems used animal symbols to explain how different parts of the human body are related to illnesses. These human body-animal associations seem to have largely originated from sympathetic magic, whereby each animal possesses specific facilities which can justify their relation to a certain part of the body, to which their "virtue" would be transmitted. In the Old World, fish, recognised for the agility of their movements, were related to feet [98]. Accordingly Table 3 shows folk remedies for the treatment of gout and knee and foot joints pains (Anguilla anguilla, Lophius piscatorius).
Dolores Carmen Morales has carried out an analysis of fish, noting the link between this animal group and reproductive apparatus and fertility:

"As for fish, the symbol of Jesus par excellence, they maintain their high reputation in Christianity due to their inheritance from other cultures. Psychic or sacred animals, fish have, however, been read in other ways: sexual interpretations because of their phallic form. Sacred Writings cite them on various occasions, possibly the most relevant reference being the miracle of the multiplying of the bread and fish. Fish are also a symbol of fertility because of the quantity of eggs produced" [99].

Thus, in Table 3 we see remedies for disorders or diseases related to the reproductive system, which follow a sympathetic magic where "like produces like", as happens with the remedies that aid childbirth, based on species such as Anguilla anguilla, Torpedo marmorata, T. torpedo, Silurus glanis or Dasyatis pastinaca; increase the production of milk with Spicara smaris and Gadus morhua; and are used as aphrodisiacs, as Anguilla anguilla and Pagellus erythinus.

We find remedies based on sympathy associated to other systems, like the application of Torpedo sp. for the treatment of diseases related to the spleen, due to its similarity in form. In the same way, otoliths or "stones from some fish" (sensitive structures to gravity and linear acceleration) are associated with the treatment of kidney stones, as in Argyrosomus regius and Merlangius merlangus (Figure 4). The red colour of Mullus barbatus

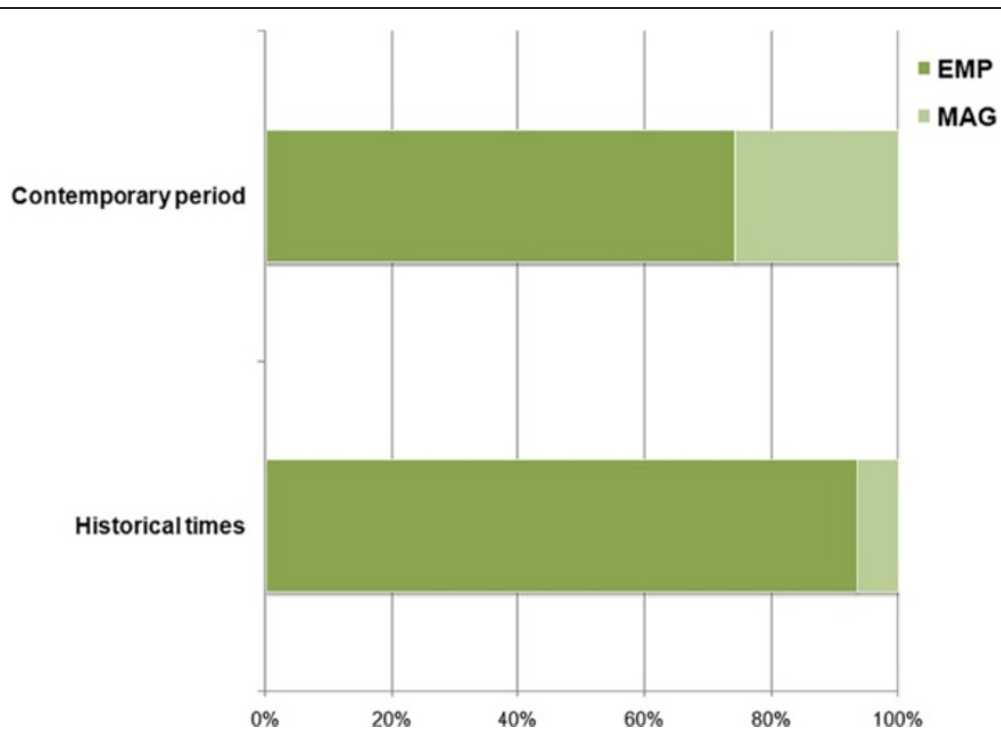

Figure 3 Relative importance of the two remedy types considered throughout Spanish medical history. EMP=empirical remedies, MAG = magical remedies 


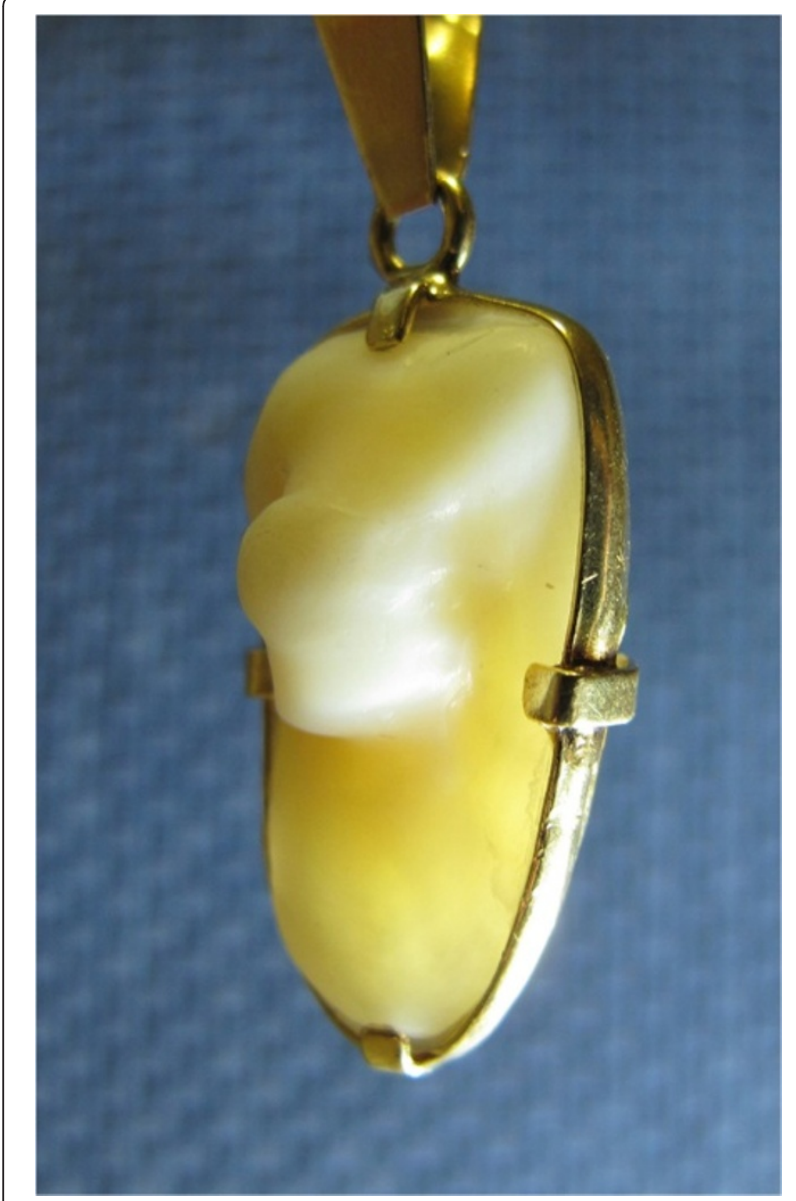

Figure 4 "Piedra de corvina" (meagre fish white stone). The otoliths of this fish species acquire a shape in which many people say that they see the face of the Virgin Mary, a fact that makes these mineral structures in a reputed protective amulet. In the pendant presented here we can see one of these otoliths mounted in gold. It belongs to the mother of one of the authors (JRV, Badajoz), who carries this jewel around her neck to prevent attacks of lumbago.

barbatus or $M$. surmuletus means that these species can be used for the treatment of menstrual disorders, and the form of the adhesive disc of the head of Remora remora explains its use in easing the implantation of the embryo in the uterus, as suggested in vernacular names "chupón", "chupona”, "ventosa” (sucker, plunger, suction pad), typical of the Cádiz and Huelva coast [100].

Hippocratic medicine was the natural philosophical foundation for therapy since antiquity up to the development of biomedicine in the 19th century. Humoralism explains the physiology of the body in terms of a balance between the four humours or fluids: black bile, yellow bile, phlegm and blood. The excess or deficiency of these humours, as a consequence of life style, would provoke diseases, disorders or conditions that would have to be corrected in order to recover health [101,102]. Juan Sorapán de Rieros, in his work Medicina española, contenida en proverbios vulgares de nuestra lengua (1616), associates one of the humours -phlegm- with fish:

"And to understand this, that of the four humours, which are in our body, one of them is called phlegm, whose nature is cold, and humid like water. It forms mainly in the stomach, and more so in winter (according to the doctrine of Hippocrates) and with food stuffs that are cold and wet, sticky and difficult to cook. Part of this phlegm stays in the stomach, and part of it passes to the liver, where in time of need, it is perfected by the body's natural heat is converted into blood. There are two differences of phlegm, one that is natural, and another that is not natural. The natural one is white and tasteless. The unnatural, is sour, or is salty, or glassy. Natural phlegm and things similar in their qualities can easily turn into each other, according to the philosopher's doctrine. Fish, in nature is cold and wet, like phlegm, and can change into it. And in this sense it is true to say that, all fish is phlegm" [103].

In Hippocratic medicine treatment by opposites or antipathy, contraria contrariis curantur, is an overriding principle which is based on primitive associations between opposites [93]. Although it's risky to interpret the remedies, we can glimpse the pharmacological conceptualization of this principle to counteract the heat and dryness of many symptoms that would be caused by stomach bile, for example by infectious diseases such as rabies, mumps, malaria and tetanus, taking advantage of the phlegm provided by Hippocampus sp., Trachurus trachurus, Perca fluviatilis or Lophius piscatorius. Digestive diseases that caused dryness or black bile would also be balanced with phlegm, thus Coris julis, Spicara smaris, Sardina pilchardus or Silurus glanis were used as laxatives.

It should be noted that although the Hippocratic Corpus constantly reported apathetic and allopathic treatments, you can also find homeopathic treatments within its pages [96,102]. Therefore we can suggest a Hippocratic origin for the remedies which use phlegm against phlegm, such as the treatment of respiratory problems with Silurus glanis.

The empirical trend based on discerning the type of remedy that was useful in the treatment of a given disease appears in the Historia de la Farmacia by Quintin Chirlone and Carlos Mallaina in 1865, where it states the following:

Is it not known, for example, that people with a putrid fever ask for acids and certain fish please those with leucorrhoea and that dysentery is characterized by a particular appetite for grapes? [104]. 
Thus, we can note that throughout history species have been selected and have been used in all historical periods because of their empirical effectiveness. Although looking back we can find critics of the popular empirical medicine such as Abü Muhammad 'Abd Allah b. Rusd in his work Acerca del método de la técnica artesanal en la terapéutica, in which he writes:

"It is clear that when a 'doctor' treats a patient with any substance, he thus provides Nature with a beginning and an end of order, whether it be in the genre of disease or of health. But if the 'doctor' is ignorant of this natural order and proper purpose and gives Nature any random beginning -I mean treating the sick with whatsoever- he may in essence be wrong but accidentally gets it right, causing more deaths than health. It is clear that ignorance of this method is the cause (fol. 79 r.) or at least one of the causes that the wise ascribes to the origin of sensation and the sensible. But we are talking about health and about disease, because most deaths occur due to the medicine" [105].

Despite the existence of detractive positions against zootherapy there currently exists objective data which demonstrate the efficiency and potential of fish as a therapeutic resource. In this regard, we underline the synthesis by Fariña Pestano et al. [6] which refers to the narcotic and analgesic active ingredients found in Tetraodontidae fish [106] - used in Japan with patients diagnosed with neurogenic leprosy and cancer [107]- to a cardiac stimulant obtained from Eptatretus stoutii Linnaeus, 1758, antitumor agents in Dasyatis sabina (Le Sueur, 1824), analgesics in Taricha sp; well as to the properties of omega-3 fatty acids obtained from shark liver in preventing atherosclerosis, hypertension, in wound healing and the stimulation of the immune system of alcoxiglycerol [108] collected by Costa-Neto [109].

Recently, researchers at the University of Almería have undertaken a study of 12 commonly consumed fish species in the southeast of Spain, demonstrating that the liver of these fish is an excellent source of fatty acids of the omega-3 family [110]. These long chain polyunsaturated fatty acids are currently used in the treatment of degenerative diseases of the nervous system and in mental health [111].

As already mentioned, the historical and therapeutic value of the fish fauna in Spanish ethnomedicine is expressed in the survival of medicinal resources belonging to, at least seven species throughout history: Acipenser sturio, Anguilla anguilla, Engraulis encrasicolus, Halobatrachus didactylus, Hippocampus sp., Scyliorhinus canicula and Squatina sp. In addition, there are 10 species of which we have only obtained records from the 20th century: Argyrosomus regius, Clupea harengus harengus, Cyprinus carpio, Dicologoglossa cuneata, Gadus morhua, Luciobarbus sclateri, Merluccius merluccius, Oxynotus centrina, Salmo trutta and Sardina pilchardus. This is particularly significant, for it indicates a dynamic Spanish ethnomedicine capable of generating new therapeutic resources in recent times. For these reasons, and taking into account that ethnomedicine in Spain is a medical system that has been virtually totally replaced by biomedicine, there is a need for further research in line with the methods and goals of the Spanish Inventory of Traditional Knowledge [112].

Coinciding with Quave and Pieroni [113] we think it is necessary to validate ethno-pharmaceutically those animal remedies that have stood the test of time, for it is this survival that is proof of its therapeutic potential and its possible applications in the pharmaceutical industry. During the 20th century, the most important groups of pathologies treated with fish-based remedies are: infectious and parasitic diseases, followed by those related to pregnancy, childbirth and postpartum, and diseases of the musculoskeletal system and connective tissue (see Table 4).

Significantly, those chapters of ICD-10 which are not represented are diseases of the nervous system and the ear and mastoid process, as well as congenital malformations, deformations and chromosomal abnormalities. Two out of three remedies used in the 20th century (74\%) are empirical, based on the humorism and the principle of contraria contrariis curantur ("the opposite is cured with the opposite"). The rest, $26 \%$, are magical type remedies that complete the popular therapeutic arsenal.

\section{A cross-cultural comparison}

Although less important than other groups of vertebrates, fishes are represented in ethnopharmacological studies related to traditional medicine of different geographic regions and human communities [10,114-116]. This fact facilitates us to carry out a cross-cultural approach in relation to current fish-based zootherapies.

The medicinal species collected in this study are not used in remote areas of the northern hemisphere, but if they are employed species belonging to some documented genera. In India the eel (Anguilla bengalensis in this case) is used: its body mucus is applied on burned zones of the body [117], and fat is applied and massage to relieve rheumatoid-arthritis pain [118]. In the same way, at Jeju Island (Korea) the salted heads of Engraulis japonica are used to treat head lacerations [119].

Comparing with the data documented by other authors for other areas of the Mediterranean Region [113,120], firstly point out that the 17 fish species used in contemporary Spanish ethnomedicine constitute a very high 
Table 4 Groups of diseases treated by fish products in Spanish ethnomedicine

\begin{tabular}{|c|c|c|c|}
\hline Chapter & Title & $\mathrm{C}_{\mathrm{i}}$ & $\mathrm{IC}_{\mathrm{i}}$ \\
\hline । & Certain infectious and parasitic diseases & 5 & 1.00 \\
\hline$\|$ & Neoplasms & 1 & 0.20 \\
\hline III & Diseases of the blood and blood-forming organs and certain disorders involving the immune mechanism & 1 & 0.20 \\
\hline IV & Endocrine, nutritional and metabolic diseases & 2 & 0.40 \\
\hline V & Mental and behavioural disorders & 3 & 0.60 \\
\hline $\mathrm{Vl}$ & Diseases of the nervous system & - & - \\
\hline VII & Diseases of the eye and adnexa & 1 & 0.20 \\
\hline VIII & Diseases of the ear and mastoid process & - & - \\
\hline IX & Diseases of the circulatory system & 3 & 0.60 \\
\hline$x$ & Diseases of the respiratory system & 2 & 0.40 \\
\hline $\mathrm{XI}$ & Diseases of the digestive system & 2 & 0.40 \\
\hline$X \|$ & Diseases of the skin and subcutaneous tissue & 1 & 0.20 \\
\hline $\mathrm{XIII}$ & Diseases of the musculoskeletal system and connective tissue & 4 & 0.80 \\
\hline XIV & Diseases of the genitourinary system & 1 & 0.20 \\
\hline $\mathrm{XV}$ & Pregnancy, childbirth and the puerperium & 4 & 0.80 \\
\hline $\mathrm{XVI}$ & Certain conditions originating in the perinatal period & 2 & 0.40 \\
\hline $\mathrm{XVII}$ & Congenital malformations, deformations and chromosomal abnormalities & - & - \\
\hline $\mathrm{XVIII}$ & Symptoms, signs and abnormal clinical and laboratory findings, not elsewhere classified & 2 & 0.40 \\
\hline $\mathrm{XIX}$ & Injury, poisoning and certain other consequences of external causes & 3 & 0.60 \\
\hline$X X$ & External causes of morbidity and mortality & 1 & 0.20 \\
\hline $\mathrm{XXI}$ & Factors influencing health status and contact with health services & 1 & 0.20 \\
\hline$X X \|$ & Codes for special purposes & - & - \\
\hline
\end{tabular}

number of therapeutic resources. And as to common species, the use of "bacalhau" (Gadus morhua) in Portugal is remarkable. In our neighboring country, this species is used against diseases such as anorexia, anemia and madness, in the treatment of abdominal pains and bone fractures, just like anti-fever and anti-parasitic [120].

These latter data induce us to discuss if there are species or similar (same family, for example) that also are used in the American countries were colonized by Spain and Portugal.

In Latin America the use of fauna with medicinal properties is a common practice since pre-Hispanic times. According to Foster [121] medical ideas and practices of indigenous peoples, along with the specific to the Spanish folklore and medieval and classical formulations have built a solid traditional medicine in this region of the world. Logically, the biogeographical differences between the Iberian Peninsula and the countries under colonization prevented the dissemination of a knowledge relate to the medicinal use of fishes at the species level. However, taxa belonging to families such as Carangidae, Engraulidae, Gadidae, Scombridae or Syngnathidae are/were used in both areas [122].
Brazil is the country where a greater number of species are used as medicines (85): 44 fresh-water species and 41 salt-water species [19]. According to a recent review [123], 77 species are consumed as food medicines. Among the fishes there documented the consumption of two genera coincides: Dasyatis, used in the Spanish medicine until the 17th century, and Gadus. In the latter case, G. morhua is the only species consumed, particularly in the treatment of furuncles. This species is also used in Brazil as a topical remedy for rheumatism and backache [19,122]. It can ensure that the Atlantic cod is a medicinal species used in force in Brazil, Portugal and Spain.

There is no doubt that the use of fishes, as a "general ethnotaxa", must be part of a cultural transfer between the New and Old World as a consequence of symbolic nature [98]. Such cultural transfer stimulated the use of certain fish species similar to those in Europe, as well as their derivatives. For example, Francisco Hernández de Toledo (1514-1587) in his book Cuatro libros de la naturaleza y virtudes de las plantas y animales de uso medicinal en la Nueva España (published in Mexico in 1615) describes the use of otoliths against kidney stones [124], also used for the same purpose in Spain. 
In the Argentine Gran Chaco region the venomous sting of the stingray Potamotrygon is used to eliminate the toothache [125] similarly to how the sting Dasyatis pastinaca was used until the early 17th century in Spain [36].

Likewise, in both geographical areas they are/were used dried seahorses (genus Hippocampus). In Spain, until the mid 20th century, these charismatic animals were only carried in the pocket or round the neck as amulets to prevent erysipleas and cure toothache (see Table 3). No longer are roasted and eaten. Conversely, in Brazil the longsnout seahorse (Hippocampus reidi) is among the most versatile fish species in terms of therapeutic indications $[19,126]$. This species is still consumed by its intake as part of different mixtures (teas, concoctions, etc.) with various medicinal plants and animals. These medicinal and/or superstitious uses put these fishes among the most traded animals for medicinal purposes. This led to the entire genus was included in May 2004 in the Appendix II of CITES, to ensure that trade is not detrimental to the survival wild populations [126].

\section{Conclusions}

Historically, fish-based therapeutics is based on a dietary usage; it has been an essential product in the care and maintenance of health from antiquity to the present. However, throughout history a wide range of pathologies have been treated through the use of these animals, and some remedies have survived to this day, highlighting especially those related to infectious and parasitic diseases, pregnancy, childbirth, puerperium and diseases of the musculoskeletal system. There is also a cultural merging, or syncretism detected in the remedies and a strong relationship exists between magic and empiricism. In the last century both were almost equally present, a period in which we also find a progressive decrease in the number of fish species used. Seven species have been documented as surviving therapeutic resources since centuries ago; the existence of a dynamic Spanish ethnomedicine has also been detected which has managed to generate new therapeutic resources in recent times. Historical ethnozoology can be a transverse axis in the history and philosophy of science; it may participate in the establishment of cultural parallels and even as ethnopharmacological research support. Despite the limited interest shown in zootherapy in Spain, it is important to evaluate it along with the rest of traditional ecological knowledge, much of which has been validated by ethnopharmacology and evidence-based medicine. In order to recover as much data as possible, it will be necessary to draw up an inventory of ethnoichthyological uses, so that it could act as an anamnesis of remedies together with the data compiled in this study. It is also important to determine the cultural significance of fish-based zootherapy and to further watch and determine how globalization and multiculturalism are influencing.

\section{Consent}

Informed consent was obtained from the people who appear in the photograph for the publication of the accompanying image.

\section{Competing interests}

Both authors declare that they have no competing interests.

\section{Authors' contributions}

The two authors contributed equally during the data collection, data analysis and preparation of the manuscript, and read and approved the final manuscript.

\section{Acknowledgments}

We would like to thank Russell York for his English technical support.

\section{Author details}

${ }^{1}$ Departamento de Terapéutica Médico-Quirúrgica, Facultad de Medicina, Universidad de Extremadura, E-06006 Badajoz, Spain. ${ }^{2}$ Grupo de Investigación de Recursos Etnobiológicos del Duero-Douro (GRIRED), Facultad de Biología, Universidad de Salamanca, E-37071 Salamanca, Spain.

Received: 2 February 2014 Accepted: 23 April 2014 Published: 30 April 2014

\section{References}

1. Santos-Fita D, Costa-Neto EM, Cano-Contreras EJ: El quehacer de la etnozoología. In Manual de Etnozoología. Una guía teórico-práctica para investigar la interconexión del ser humano con los animales. Edited by Costa-Neto EM, Santos-Fita D, Vargas-Clavijo M. Valencia: Tundra Ediciones; 2009:23-44.

2. Costa-Neto EM: Manual de Etnoentomología. Zaragoza: Sociedad Entomológica Aragonesa (S.E.A.); 2002.

3. Alves RRN, Vieira KS, Santana GG, Vieira WL, Almeida WO, Souto WM, Montenegro PF, Pezzuti JC: A review on human attitudes towards reptiles in Brazil. Environ Monit Assess 2012, 184(11):6877-6901.

4. De Farias $G B$, Chaves Alves ÂG: Aspectos históricos e conceituais da etnoornitologia. Biotemas 2007, 20(1):91-100.

5. Clauzet $M$, Ramires M, Begossi A: Etnoictiologia dos pescadores artesanais da praia de Guaibim, Valença (BA). Brasil Neotrop Biol Conserv 2007 2(3):136-154.

6. Fariña Pestano AR, Ruiz Velásquez LJ, Rojas Flores MY, Peñuela Jiménez JH, González Henríquez MN: Etnobiología marina y aspectos pesqueros en seis comunidades costeras de la Península de Paria. Venezuela Interciencia 2011, 36(4):256-264.

7. Pinto MF, Mourão JS, Alves RRN: Ethnotaxonomical considerations and usage of ichthyofauna in a fishing community in Ceará State. Northeast Brazil J Ethnobiol Ethnomed 2013, 9:17.

8. Alves RRN, Rosa IL: From cnidarians to mammals: the use of animals as remedies in fishing communities in NE Brazil. J Ethnopharmacol 2006, 107:259-276.

9. Alves RRN, Rosa IL: Zootherapeutic practices among fishing communities in North and Northeast Brazil: a comparison. J Ethnopharmacol 2007, 111:82-103

10. Deb AK, Haque CE: 'Every mother is a mini-doctor': ethnomedicinal uses of fish, shellfish and some other aquatic animals in Bangladesh. J Ethnopharmacol 2011, 134(2):259-267.

11. Orilogbon JO, Adewole AM: Ethnoichthyological knowledge and perception in traditional medicine in Ondo and Lagos States, southwest Nigeria. Egyptian J Biol 2011, 13:57-64.

12. Begossi A, Ramires M: Fish folk medicine of Caiçara (Atlantic Coastal forest) and Caboclo (Amazon forest) communities. In Animals in Traditional Folk Medicine. Edited by Alves RRN, Rosa IL. New York: Springer; 2013:91-108.

13. Alves RRN: Zooterapia: importancia, usos e implicaciones conservacionistas. In Manual de Etnozoología. Una guía teórico-práctica para investigar la interconexión del ser humano con los animales. Edited by Costa-Neto EM, Santos-Fita D, Vargas-Clavijo M. Valencia: Tundra Ediciones; 2009:165-175. 
14. Alves RRN, Rosa IL: Introduction: toward a plural approach to the study of medicinal animals. In Animals in Traditional Folk Medicine. Edited by Alves RRN, Rosa IL. New York: Springer; 2013:1-10

15. Mohanty BP, Sudheesan D, Sankar TV, Das MK, Sharma AP: Therapeutic Value of Fish. Central Indian Fisheries Research Institute: Barrackpore, Kolkata; 2011.

16. Alves RRN, Albuquerque UP: Animals as a source of drugs: bioprospecting and biodiversity conservation. In Animals in Traditional Folk Medicine. Edited by Alves RRN, Rosa IL. New York: Springer; 2013:67-90.

17. Alves RRN, Rosa IL: Why study the use of animal products in traditional medicines? J Ethnobiol Ethnomed 2005, 1:5.

18. Alves RRN: Relationships between fauna and people and the role of ethnozoology in animal conservation. Ethnobio Conserv 2012, 1:2.

19. El-Deir ACA, Collier CA, Almeida Neto MS, Silva KMS, Policarpo IS, Araújo TAS, Alves RRN, Albuquerque UP, Moura GJB: Ichthyofauna used in traditional medicine in Brazil. Evid Based Complement Alternat Med 2012, 2012:Article ID 474716

20. Sánchez Gómez LA: Etnozoología y Antropología. RDTP 1994 49(2):171-204

21. Benítez G: Animals used for medicinal and magico-religious purposes in western Granada Province, Andalusia (Spain). J Ethnopharmacol 2011, 137(3):1113-1123.

22. González JA, Vallejo JR: The scorpion in Spanish folk medicine: a review of traditional remedies for stings and its use as a therapeutic resource. J Ethnopharmacol 2013, 146(1):62-74.

23. Vallejo JR, González JA: The use of the head louse as a remedy for jaundice in Spanish folk medicine: an overview. J Ethnobiol Ethnomed 2013, 9:52.

24. Borràs L: Los artículos lexicográficos de zoónimos en diccionarios españoles de lengua general. In PhD thesis. Barcelona: Universitat Pompeu Fabra, Institut Universitari de Lingüística Aplicada; 2004

25. De Vos P: European materia medica in historical texts: longevity of a tradition and implications for future use. J Ethnopharmacol 2010 132:28-47.

26. Cantó J, Gómez Santamaría I, González Marín S, Tarriño E: Plinio, Historia Natural. 2nd edition. Madrid: Cátedra; 2007.

27. López Eire A: Dioscórides Interactivo sobre los remedios medicinales: manuscrito de Salamanca, Project MICINN HUM-2006-08794. Salamanca: Ediciones Universidad de Salamanca; [http://dioscorides.eusal.es/]

28. Vara Donado J: Claudio Eliano, Historia de los animales. Madrid: Akal; 1989.

29. Anonymous: El Libro Magno de San Cipriano (facsimile edition). Barcelona: Humanitas; 1985.

30. de Morales Álvarez C, Girón Irueste F: Abd al-Malik Ibn Habib: Mujtasar fi I-tibb (Compendio de medicina). Madrid: ICMA-CSIC; 1992.

31. Arvide Cambra LM: Un tratado de cosmética en Abulcasis. Grupo Editorial Universitario: Granada; 2010.

32. de Morales Álvarez C: Ibn Wafid. Kitab al-Wisad fi l-tibb = Libro de la almohada, sobre medicina. Toledo: Diputación Provincial de Toledo; 2006

33. Cabo González AM: Ibn al-Baytar al-Malaqi: Colección de Medicamentos y Alimentos. Mergablum: Sevilla; 2005

34. Ruiz Bravo-Villasante C: Libro de las utilidades de los animales. Madrid: Fundación Universitaria Española; 1980.

35. Viñayo A, Riesco HB: Hortus Sanitatis. De Avibus et Piscibus (facsimile edition) León: Universidad de León; 1998.

36. de Arciniega Vélez F: Historia de los animales mas recebidos en el uso de medicina: donde se trata para lo que cada uno entero ò parte del aprovecha y de la manera de su preparacion. Madrid: Imprenta Real; 1613.

37. Daza Chacón D: Pratica y teorica de cirugia en romance y en latin. Valencia: Francisco Cipres; 1673

38. Palacios F: Palestra farmaceutica, chymico-galenica: En la qual se trata de la eleccion de los simples, sus preparaciones chimicas, y galénicas, y de las mas selectas composiciones antiguas, y modernas... Muy añadida en esta última impresion. Madrid: Imprenta de la Viuda de D. Joaquín Ibarra; 1792.

39. de Plancy JAS C: Diccionario infernal, ó sea cuadro general de los seres, personajes, libros, hechos y cosas que hacen referencia a las apariciones, á la magia blanca y negra, al comercio del infierno. Barcelona: Imprenta de los Hnos. Llorens; 1842.

40. Nogales J: Apuntes para el Folk-lore bético-extremeño. Prácticas y creencias populares en el Suroeste de España. Rev Extremadura 1907, 9:145-167.

41. Rodríguez López J: Supersticiones de Galicia. Madrid: Imprenta de Ricardo Rojas; 1910
42. Sánchez Pérez JA: Supersticiones españolas. Madrid: Saeta; 1948.

43. Barriola IM: La medicina popular en el País Vasco. Biblioteca Vascongada de los Amigos del País: San Sebastián; 1952.

44. Cascón V: Notas varias en la Sierra de Francia. Hojas Folklóricas 1952, 43:170.

45. de Lucas Castillo A: Folkmedicina. Madrid: Editorial Dossat; 1958.

46. Seijo Alonso FG: Curanderismo y medicina popular (en el País Valenciano). Ediciones Biblioteca Alicantina: Alicante; 1974

47. Alvar M: Atlas Lingüístico y Etnográfico de Aragón, Navarra y Rioja (ALEANR). Madrid-Zaragoza: CSIC-Institución "Fernando el Católico"; 1979-1983.

48. Becoña Iglesias E: La actual medicina popular gallega. 2nd edition. La Coruña: Imprenta Magoygo (author's edition); 1981.

49. Carril Á: Veterinaria y medicina popular en Salamanca. Rev Folklore 1981, 5:27-32.

50. Blanco JF: Medicina y veterinaria populares en la provincia de Salamanca. 2nd edition. Salamanca: Diputación de Salamanca; 1985.

51. Erkoreka A: Desaparición de los rituales y creencias asociados al recién nacido. Zainak 1988, 6:193-200.

52. Vázquez Gallego X: Tradiciones, mitos, creencias y curanderismo en medicina popular de Galicia. Diputación Provincial de Lugo: Lugo; 1989.

53. Barandiarán JM: Recetas y remedios en la medicina popular vasca. Txertoa: San Sebastián; 1990

54. García Arambilet LÁ: Medicina popular en la provincia de Soria: descripción y análisis de sus prácticas. In Degree thesis. Salamanca: Universidad de Salamanca; 1990.

55. Garmendia Larrañaga J: Rito y fórmula en la medicina popular vasca. La salud por las plantas medicinales. Txertoa: San Sebastián; 1990.

56. Carril Á: Etnomedicina. Acercamiento a la terapéutica popular. Castilla Ediciones: Valladolid; 1991.

57. Jordán JF, de la Peña A: Mentalidad y tradición en la Serranía de Yeste y Nerpio. Instituto de Estudios Albacetenses: Albacete; 1992

58. Fragua Gil S: Antropología médica de la Villa de Coca (Segovia). In PhD thesis. Madrid: Universidad Complutense de Madrid; 1994

59. Gil Barberá J, Martí Mora E: Medicina valenciana mágica y popular. Carena Editors: Valencia; 1997

60. Domínguez Moreno JM: Etnomedicina respiratoria en Extremadura (I). Rev Folklore 2000, 229:3-11.

61. Dueso J: Medicina popular vasca. Roger Editor: San Sebastián; 2001

62. Erkoreka A: Análisis de la medicina popular vasca. Bibliotex: Barcelona; 2002.

63. Álvarez Peña A: Melecina máxico-tradicional n'Asturies. VTP Editorial: Gijón (Asturias); 2004

64. Barandiarán JM: Manterola A (dirs.): Medicina popular en Vasconia. Etniker Euskalerria - Eusko Jaurlaritza - Gobierno de Navarra: Bilbao; 2004.

65. Domínguez Moreno JM: Dermatología popular en Extremadura (III). Rev Folklore 2004, 288:183-193.

66. González Salgado JA: El folklore en los Atlas Lingüísticos españoles (II): medicina popular y supersticiones. Rev Folklore 2004, 280:125-129.

67. López Pérez M: La cultura popular natalicia: El arte de amamantar en el Campo de Cartagena. Rev Murc Antropol 2004, 10:219-226.

68. Domínguez Moreno JM: Dermatología popular en Extremadura (y IV) granos. Rev Folklore 2005, 297:88-97.

69. Vallejo JR, Peral D, Vázquez F, Martín P: Conocimiento y uso de la medicina popular en ancianos de Guadiana del Caudillo. Rev Est Extremeños 2005, 61:79-101.

70. Hernández Ortega J: Una aproximación a la medicina popular en La Aparecida (Alicante). Culturas Populares Rev Electr 2007, 4: [http://www. culturaspopulares.org/textos4/articulos/hernandezortega.pdf]

71. Pérez Vidal J: Contribución al estudio de la medicina popular canaria. Ediciones IDEA: Santa Cruz de Tenerife; 2007

72. Castelló J, Ambou V, Castelló JC: Estudio sobre la medicina tradicional en La Vall d'Uixó: Una aproximación desde la etnomedicina. La Vall d'Uixó (Castellón): IES Benigasló; 2008 [http://www.esdelibro.es/archivos/trabajos08/ 200800022_etnomedicina_trabajo.pdf]

73. Muriel Martín MP: La medicina popular en la provincia de Palencia. Institución Tello Téllez de Meneses - Diputación de Palencia: Palencia; 2008.

74. de Santayana Pardo M: Estudios etnobotánicos en Campoo (Cantabria). Conocimiento y uso tradicional de plantas. Madrid: CSIC; 2008.

75. Vallejo JR: La Etnomedicina en Guadiana del Caudillo (Badajoz) In PhD thesis. Badajoz: Universidad de Extremadura, Facultad de Medicina; 2008 
76. Alemany $S$, Francès $L$, Subirós R: Recull de remeis tradicionals als pobles pescadors de la Costa Brava. Rev Etnol Catalunya 2010, 36:151-154.

77. Cobo López MP, Tijera Jiménez RE: Etnozoología de Doñana. Mancomunidad de Desarrollo y Fomento del Aljarafe: Sevilla; 2013.

78. Rigat M, Vallès J, Iglésias J, Garnatje T: Traditional and alternative natural therapeutic products used in the treatment of respiratory tract infectious diseases in the eastern Catalan Pyrenees (Iberian Peninsula). J Ethnopharmacol 2013, 148(2):411-422.

79. de Buen F: Fauna ictiológica. Catálogo de los peces ibéricos de la planicie continental, aguas dulces, pelágicos y de los abismos próximos. Madrid: Ministerio de Marina; 1935

80. Lindberg GU: Fishes of the World. A key of families and checklist. New York: John Wiley Sons; 1974

81. FROM (Ministerio de Agricultura, Pesca y Alimentación, Secretaria General de Pesca Marítima): Catálogo de denominaciones de especies acuícolas españolas. Propuesta de normalización de las 250 especies de mayor interés económico. Tomo I: Peces. Madrid: FROM - Secretaría General de Pesca y Alimentación; 1985.

82. Nelson JS: Fishes of the World. 4th edition. Hoboken (NJ): Wiley; 2006.

83. Marine Species: Identification Portal. [http://species-identification.org]

84. FishBase. [www.fishbase.org]

85. Fishwise: universal fish catalogue. [www.fishwise.co.za]

86. WoRMS: World Register of Marine Species. [www.marinespecies.org]

87. ICTIOTERM: Base de datos terminológicos y de identificación de especies pesqueras de las costas de Andalucía. [www.ictioterm.es]

88. Roskov Y, Kunze T, Paglinawan L, Orrell T, Nicolson D, Culham A, Bailly N, Kirk P, Bourgoin T, Baillargeon G, Hernández F, De W (Eds): Species 2000 \& ITIS Catalogue of Life, 2013 Annual Checklist. [www.catalogueoflife.org/ annual-checklist/2013/]

89. ICD-10 Version. 2010 [http://apps.who.int/classifications/icd10/browse/ 2010/en]

90. Laguna A: Acerca de la materia medicinal... Salamanca 1566. facsimileth edition. Barcelona: MRA; 1994

91. Delgado Ruiz M: Magia. In Diccionario Temático de Antropología. Edited by Aguirre Baztán A. Barcelona: Marcombo; 1993:408-411.

92. Rodríguez Becerra S: Superstición. In Diccionario Temático de Antropología. Edited by Aguirre Baztán A. Barcelona: Marcombo; 1993:587-591.

93. Gil L: Therapeia. La medicina popular en el mundo clásico. Madrid: Triacastela; 2004.

94. Mackinney LC: Animal substances in materia medica, a study in the persistence of the primitive. J Hist Med Allied Sci 1946, 1:149-170.

95. Cohen M: Poder curar. Del Signo: Buenos Aires; 2004.

96. Laín Entralgo P: La curación por la palabra en la Antigüedad clásica. 2nd edition. Anthropos: Rubí (Barcelona); 2005.

97. Vernia P: La farmacopea valenciana. Seriols-Sichet-Herrero: Villareal (Castellón); 1981

98. De María y Campos T: Los animales en la medicina tradicional mesoamericana. An Antropol 1979, 16:183-223.

99. Morales Muñiz MDC: El simbolismo animal en la cultura medieval. Espacio, Tiempo y Forma. Serie III. Hist Medieval 1996, 9:229-255.

100. Arias AM, de la Torre M, Fijo MI: ICTIOTERM: Base de datos terminológicos y de identificación de especies pesqueras de las costas de Cádiz y Huelva. 2013 [http://www.ictioterm.es/]

101. Laín Entralgo P: La medicina hipocrática. Madrid: Alianza Universidad; 1982

102. Guerra F: Historia de la Medicina. 3rd edition. Madrid: Ediciones NormaCapitel; 2007.

103. de Lucas Castillo A, de Rieros Sorapán J: Medicina española contenida en proverbios vulgares de nuestra lengua. Madrid: Real Academia Nacional de Medicina; 1975.

104. Chirlone Q, Mallaina C: Historia de la Farmacia. 2nd edition. Madrid: Imprenta de José M. Ducazcal; 1865

105. de Benito MC V: La medicina de Averroes: comentarios a Galeno. Salamanca: Ediciones Universidad de Salamanca; 1987.

106. Bisset NG: One man's poison, another man's medicine? J Ethnopharmacol 1991, 32(1-3):71-81.

107. Colwell RR: Microbial biodiversity and biotechnology. In Biodiversity II: Understanding and Protecting Our Biological Resources. Edited by Reaka-Kudla ML, Wilson DE, Wilson EO. Washington DC: Joseph Henry Press; 1997:77-98.

108. Adeodato S: Os santos remédios do mar. Globo Ciência 1997, 4:20-25.
109. Costa-Neto EM: Healing with animals in Feira de Santana City, Bahia. Brasil J Ethnopharmacol 1999, 65(3):225-230.

110. Guil-Guerrero JL, Venegas-Venegas E, Rincón-Cervera MÁ, Suárez MD: Fatty acid profiles of livers from selected marine fish species. J Food Comp Anal 2011, 24(2):217-222.

111. Sanjurjo Crespo P: Nutrición infantil y salud mental en el niño y en el adulto. Acta Pediatr Esp 2008, 66(8):399-408

112. de Santayana Pardo M, Morales R, Aceituno L, Molina M, Tardío J: Etnobiología y Biodiversidad: el Inventario Español de los Conocimientos Tradicionales. Ambienta 2012, 99:6-24.

113. Quave CL, Pieroni A: Mediterranean Zootherapy: A Historical to Modern Perspective. In Animals in Traditional Folk Medicine. Edited by Alves RRN, Rosa IL. New York: Springer; 2013:303-316.

114. Lohani U: Man-animal relationships in Central Nepal. J Ethnobio Ethnomed 2010, 6:31.

115. Barros FB, Varela SAM, Pereira HM, Vicente L: Medicinal use of fauna by a traditional community in the Brazilian Amazonia. J Ethnobiol Ethnomed 2012, 8:37.

116. Azmi HK, Singh R: The role of medicinal fishes in relation to health care among the Gond tribal of Chhatisgarh. Indian J L Sci 2013, 3(1):79-81.

117. Chakravorty J, Meyer-Rochow VB, Ghosh S: Vertebrates used for medicinal purposes by members of the Nyishi and Galo tribes in Arunachal Pradesh (North-East India). J Ethnobiol Ethnomed 2011, 7:13.

118. Teronpi V, Singh HT, Tamuli AK, Teron R: Ethnozoology of the Karbis of Assam, India: Use of ichthyofauna in traditional health-care practices. Ancient Sci Life 2012, 32(2):99-103.

119. Kim H, Song M-J: Ethnozoological study of medicinal animals on Jeju Island, Korea. J Ethnopharmacol 2013, 146(1):75-82.

120. Ceríaco LMP: A Review of Fauna Used in Zootherapeutic Remedies in Portugal: Historical Origins, Current Uses, and Implications for Conservation. In Animals in Traditional Folk Medicine. Edited by Alves RRN, Rosa IL. New York: Springer; 2013:317-346.

121. Foster GM: Relationships between Spanish and Spanish-American Folk Medicine. J Am Folklore 1953, 66(261):201-217

122. Alves RRN, Alves HN: The faunal drugstore: Animal-based remedies used in traditional medicines in Latin America. J Ethnobiol Ethnomed 2011, 7:9.

123. Alves RRN, Oliveira TPR, Rosa IL: Wild animals used as food medicine in Brazil. Evid Based Complement Alternat Med 2013, 2013:Article 670352.

124. de Toledo Hernández F: Cuatro libros de la naturaleza y virtudes de las plantas y animales de uso medicinal en la Nueva España. [http://www.wdl. org/es/item/7334/]

125. Martínez GJ: Use of fauna in the traditional medicine of native Toba (qom) from the Argentine Gran Chaco region: an ethnozoological and conservational approach. Ethnobio Conserv 2013, 2:2

126. Rosa IL, Defavari GR, Alves RRN, Oliveira TPR: Seahorses in Traditional Medicines: A Global Overview. In Animals in Traditional Folk Medicine Edited by Alves RRN, Rosa IL. New York: Springer; 2013:207-240.

doi:10.1186/1746-4269-10-37

Cite this article as: Vallejo and González: Fish-based remedies in Spanish ethnomedicine: a review from a historical perspective. Journal of Ethnobiology and Ethnomedicine 2014 10:37

\section{Submit your next manuscript to BioMed Central and take full advantage of:}

- Convenient online submission

- Thorough peer review

- No space constraints or color figure charges

- Immediate publication on acceptance

- Inclusion in PubMed, CAS, Scopus and Google Scholar

- Research which is freely available for redistribution 